\title{
A Three-Dimensional Coupled Hydrodynamic-Ecological Modeling to Assess the Planktonic Biomass in a Subalpine Lake
}

\author{
Wen-Cheng Liu ${ }^{1} * \mathbb{Q}$, Hong-Ming Liu ${ }^{1}$ and Rita Sau-Wai Yam ${ }^{2}$ \\ 1 Department of Civil and Disaster Prevention Engineering, National United University, Miaoli 360302, Taiwan; \\ dslhmd@gmail.com \\ 2 Department of Bioenvironmental Systems Engineering, National Taiwan University, Taipei 10617, Taiwan; \\ ritayam@ntu.edu.tw \\ * Correspondence: wcliu@nuu.edu.tw; Tel.: +886-37-382357
}

check for

updates

Citation: Liu, W.-C.; Liu, H.-M.; Yam, R.S.-W. A Three-Dimensional Coupled Hydrodynamic-Ecological Modeling to Assess the Planktonic Biomass in a Subalpine Lake. Sustainability 2021, 13, 12377. https://doi.org/10.3390/su132212377

Academic Editors: Fadong Li,

Gang Chen, Xinlin He

and Guang Yang

Received: 3 September 2021

Accepted: 3 November 2021

Published: 9 November 2021

Publisher's Note: MDPI stays neutral with regard to jurisdictional claims in published maps and institutional affiliations.

Copyright: (c) 2021 by the authors. Licensee MDPI, Basel, Switzerland. This article is an open access article distributed under the terms and conditions of the Creative Commons Attribution (CC BY) license (https:/ / creativecommons.org/licenses/by/ $4.0 /)$.

\begin{abstract}
In this study, a coupled three-dimensional hydrodynamic-ecological model was developed to comprehensively understand the interaction between the hydrodynamics and ecological status of a lake. The coupled model was utilized to explore the hydrodynamics, water quality, and ecological status in an ecologically rich subalpine lake (i.e., Tsuei-Feng Lake (TFL), located in north-central Taiwan). The measured data of water depth, water temperature, water quality, and planktonic biomass were gathered to validate the coupled model. The simulated results with a three-dimensional hydrodynamic and water quality-ecological model reasonably reproduced the variations in observed water depth, water temperature, water quality, and phytoplankton and zooplankton biomass. Sensitivity analysis was implemented to determine the most influential parameter affecting the planktonic biomass. The results of sensitivity analysis indicated that the predation rate on phytoplankton (PRP) significantly affects the phytoplankton biomass, while the basal metabolism rate of zooplankton (BMZ) importantly affects the zooplankton biomass. Furthermore, inflow discharge was the most important environmental factor dominating the phytoplankton and zooplankton biomass of TFL. This implies that the runoff in the catchment area caused by rainfall and the heavy rainfall induced by climate change may affect the planktonic biomass of the lake.
\end{abstract}

Keywords: hydrodynamic-ecological modeling; phytoplankton; zooplankton; water quality; SCHISMEcol; Tsuei-Feng Lake

\section{Introduction}

Freshwater lakes provide important and valuable resources such as water supply, environmental and ecological services, recreation, and landscape appreciation. Due to rapid economic development, population expansion, and land cultivation, watershed areas have been overly developed, resulting in excessive nutrient input into lakes during rainfall, causing serious damage to water quality and eutrophication and even resulting in an imbalance of ecosystems. Therefore, reducing external nutrient loads into lakes to prevent deterioration of water quality and eutrophication for sustainable lake management has become an extremely important task [1-6].

To fully understand the water quality and ecological health of lakes, on-site observation is an indispensable measure. However, no matter how dense the number of measurement stations is, the water quality and ecological conditions in spatial and temporal distributions are still insufficient, and the cost of on-site observation is too expensive. Another alternative is to utilize mathematical modeling, which can be employed to describe spatiotemporal variations in hydrodynamics, water quality, and ecological variables and can be applied to predict the water quality and ecological conditions due to human activities and after adjustment strategies [7-9]. Moreover, coupled hydrodynamic-ecological models have become useful and effective tools for exploring the interactions among physical, biogeochemical, and ecological processes and for further water quality and ecological 
management in surface waters [10-14]. These models have been widely developed and applied to different water bodies, such as lakes, reservoirs, wetlands, rivers, estuaries, bays, and oceans [15-22].

Recently, different kinds of one-dimensional, two-dimensional, and three-dimensional hydrodynamic-ecological coupled models have been developed and applied to investigate water quality and ecosystems in lakes [8,16,23-31]. The one-dimensional and twodimensional hydrodynamic-ecological coupled models are not so complicated for running the models to obtain the simulation results with minimal computational cost for evaluating water quality and ecological status in lakes, but these kinds of models are not utilized to resolve the horizontal and vertical dimensions simultaneously. Therefore, threedimensional hydrodynamic-ecological coupled models display useful tools to obtain such information for environmental assessment and management, even though they require more computational resources [31].

Due to the complex bathymetry and topography of lakes as well as the complexity of the water environment in lakes, the development of a coupled three-dimensional hydrodynamic-ecological model based on the transport and transformation processes of flow, pollutants, and ecological variables is urgently necessary. The objective of this study was to develop a three-dimensional hydrodynamic-ecological coupled model (SCHISMEcol) to simulate the hydrodynamics, water quality, and biomass of phytoplankton, zooplankton, and fish in Tsuei-Feng Lake (TFL), which is located in the north-central mountains of Taiwan. The coupled model was validated with observations of water depth, water temperature, water quality, and planktonic biomass. The model sensitivity analysis of parameters was conducted with the validated model to determine the important parameters affecting the biomasses of phytoplankton and zooplankton. The validated model was then applied to explore when the lake's environment changed, which was the most crucial environmental factor affecting the planktonic biomass.

\section{Materials and Methods}

\subsection{Description of the Study Site and Data}

Tsuei-Feng Lake (TFL) is one of the largest alpine lakes in Taiwan. It is located in the mountainous area of north-central Taiwan between Taiping Mountain and Dayuan Mountain (Figure 1). TFL is surrounded by a secondary cypress forest that was replanted five decades ago after selective logging [32]. It has an altitude of $1850 \mathrm{~m}$ and a circumference of $600 \mathrm{~m}$. It is shaped like a gourd, measuring $160 \mathrm{~m}$ wide at its widest point and $15 \mathrm{~m}$ at its narrowest point. The annual precipitation in the lake exceeds $3600 \mathrm{~mm}$, and the mean annual temperature is approximately $13.4^{\circ} \mathrm{C}$. The period of full water level is from September to November, especially affected by typhoons, with an area of up to 25 ha and a depth of $7 \mathrm{~m}$. During the dry season from January to April, a large area of grassland is exposed, making the lake appear as a large lake and a small lake, with a total area of 8 ha and a depth of $3 \mathrm{~m}$ [33]. As it is located in the Taiping Mountain National Forest Recreation Area (TMNFRA), there is a trail around TFL to provide tourists with recreation and sightseeing services. The principle of ecological engineering was employed throughout in the construction of the trail, and care was taken to avoid destroying the original surface and disturbing the underlying biological features. TFL has a more obvious inflow to the southeast of the lake and an outflow to the northwest of the lake. The deepest part of its bottom is $4.56 \mathrm{~m}$, and a monitoring station buoy was set up (see Figure 1). According to Chiu et al. [32], the degree of eutrophication is between mesotrophic and eutrophic. The concentration of total phosphorus ranged from 10 to $70 \mu \mathrm{g} / \mathrm{L}$, and the mean dissolved organic carbon and $\mathrm{pH}$ were $2.9 \mathrm{mg} / \mathrm{L}$ and 5.9 , respectively. 


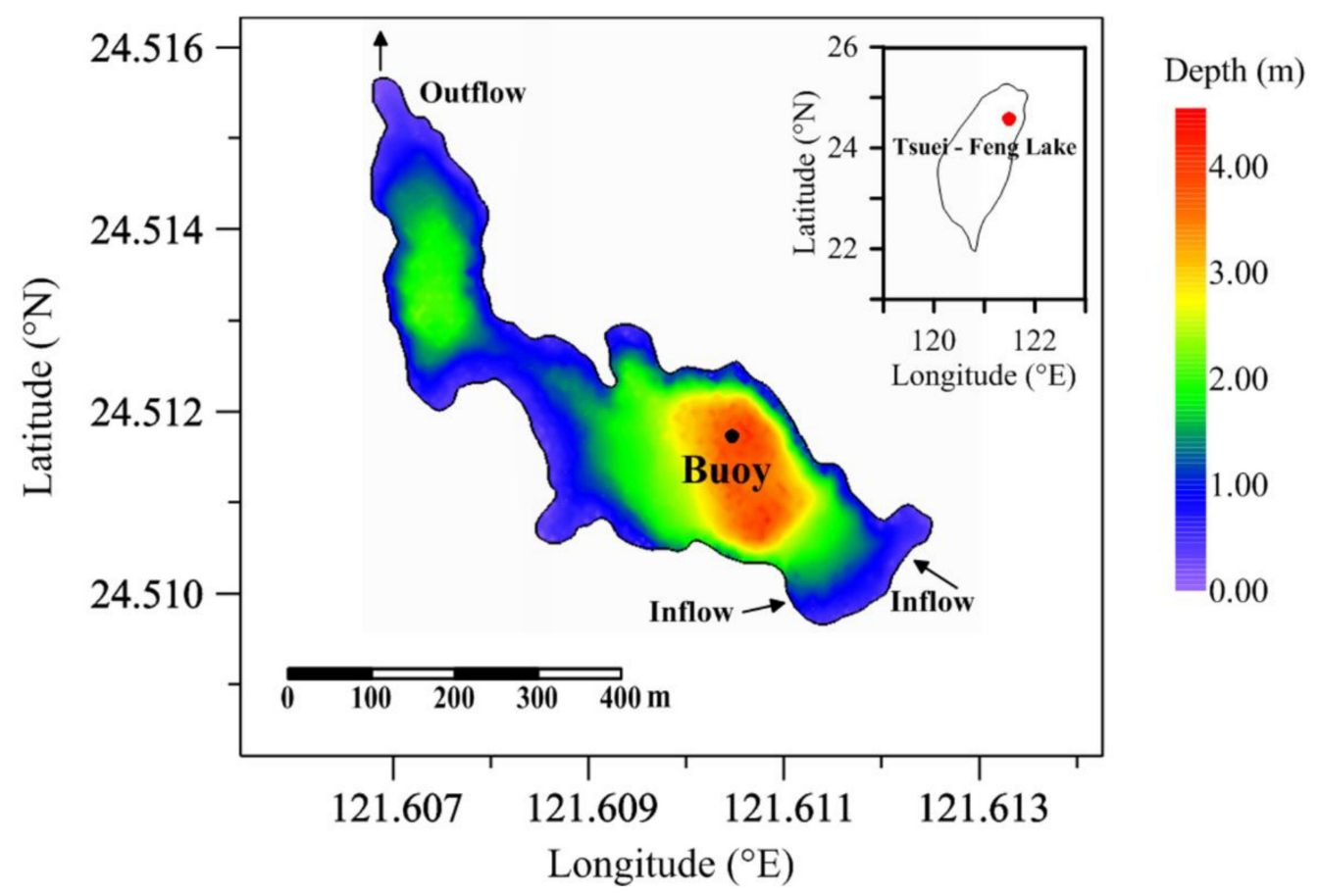

Figure 1. Map showing the depth of the lake and the location of the buoy, inflow, and outflow in Tsuei-Feng Lake (TFL).

The water depth, water temperature, and meteorological data were all obtained from the buoy station every ten minutes using autonomous sensors. The dissolved oxygen (DO) was measured in situ with a DO sensor. The lake water samples were sampled and taken back to the laboratory for measuring nutrients (ammonium nitrogen, dissolved organic nitrogen, phosphorus, and dissolved organic phosphorus), dissolved organic carbon (DOC), and ecological state variables (phytoplankton biomass and zooplankton biomass). These measured data were collected in 2017 and 2018 and were utilized for hydrodynamic-ecological model validation.

In order to collect the phytoplankton and zooplankton data, a water sample of $1 \mathrm{~L}$ was collected at $0-50 \mathrm{~cm}$ water depth from the lake surface for the determination of phytoplankton biomass. Zooplankton sample was collected in the study lake by filtering $5 \mathrm{~L}$ water sample obtained from $0-50 \mathrm{~cm}$ water depth from the lake surface with zooplankton sampling net $($ mesh size $=330 \mu \mathrm{m})$. Three replicates of phytoplankton and zooplankton samples were collected at TFL during each sampling. Both phytoplankton and zooplankton samples were fixed with formaldehyde, stored in labeled bottoms and transported back to the laboratory at $4{ }^{\circ} \mathrm{C}$. In the laboratory, individual water samples were passed through pre-combusted Whatmann GF/F $0.7 \mu \mathrm{m}$ filters to collect particulate organic matter (POM), which is composed of mainly ( $\geq 93 \%)$ phytoplankton in a mixture of phytoplankton and detritus. The relative importance of phytoplankton in the POM was confirmed by microscopic examination at the 500-1000x magnification of $100 \mathrm{~mL}$ subsample from each water sample. Each zooplankton sample was examined at 80-100x magnification using a Leica research microscope, and identified into three taxa (i.e., Copepoda, Cladocera, and Rotifera) to make a composite sample. The relative abundance of each taxon in each zooplankton sample was calculated and recorded. Prior to further analysis, the individual phytoplankton samples and zooplankton samples were dried at $60{ }^{\circ} \mathrm{C}$ to constant weight. After drying, samples were homogenized in an agate mortar, recorded in dry weight (to the nearest $0.1 \mathrm{mg}$ ), and stored in a desiccator. The biomass of the phytoplankton and zooplankton samples were determined by dividing the dry weight with the corresponding volume of the field-collected water samples $(\mathrm{mg} / \mathrm{L})$. Triplicates of phytoplankton and zooplankton samples $(\sim 2.0 \mathrm{mg})$ were put into tin capsules and weighed with an accuracy 
of $\pm 1 \mu \mathrm{g}$. The samples were analyzed by the elemental analyzer (NA 1500, Fison, Italy) in the Plant Ecophysiological Lab of National Taiwan University. The results were expressed as \% amount of carbon in each sample, and these values can be converted to carbon content (C) of the samples (mg C/L) by back-calculated with their weight.

\subsection{Hydrodynamic Model}

A three-dimensional semi-implicit cross-scale hydroscience integrated system model (SCHISM) was employed to simulate the hydrodynamics in the lake [34,35]. The model is an open-source supported modeling system derived from the early version of the SELFE model [36]. SCHISM adopts an efficient and accurate semi-implicit and finite-volume method with an Eulerian-Lagrangian algorithm to solve the turbulence-averaged NavierStokes equations under hydrostatic and Boussinesq approximations. The governing equations of SCHISM can be expressed as follows.

The continuity equation is

$$
\frac{\partial u}{\partial x}+\frac{\partial v}{\partial y}+\frac{\partial w}{\partial z}=0
$$

The momentum equation is

$$
\begin{aligned}
& \frac{D u}{D t}=f v-g \frac{\partial \eta}{\partial x}-\frac{1}{\rho_{0}} \frac{\partial p_{a}}{\partial x}-\frac{g}{\rho_{0}} \int_{z}^{\eta} \frac{\partial \rho}{\partial x} d z+\frac{\partial}{\partial x}\left(K_{m x} \frac{\partial u}{\partial x}\right)+\frac{\partial}{\partial y}\left(K_{m y} \frac{\partial u}{\partial y}\right)+\frac{\partial}{\partial z}\left(K_{m z} \frac{\partial u}{\partial z}\right) \\
& \frac{D v}{D t}=-f u-g \frac{\partial \eta}{\partial y}-\frac{1}{\rho_{0}} \frac{\partial p_{a}}{\partial y}-\frac{g}{\rho_{0}} \int_{z}^{\eta} \frac{\partial \rho}{\partial y} d z+\frac{\partial}{\partial x}\left(K_{m x} \frac{\partial v}{\partial x}\right)+\frac{\partial}{\partial y}\left(K_{m y} \frac{\partial v}{\partial y}\right)+\frac{\partial}{\partial z}\left(K_{m z} \frac{\partial v}{\partial z}\right)
\end{aligned}
$$

The mass balance transport equation is

$$
\frac{\partial C}{\partial t}+\frac{\partial(u C)}{\partial x}+\frac{\partial(v C)}{\partial y}+\frac{\partial(w C)}{\partial z}=\frac{\partial}{\partial x}\left(K_{c x} \frac{\partial C}{\partial x}\right)+\frac{\partial}{\partial y}\left(K_{c y} \frac{\partial C}{\partial y}\right)+\frac{\partial}{\partial z}\left(K_{c z} \frac{\partial C}{\partial z}\right)
$$

The equation of state is

$$
\rho=\rho(T, p)
$$

where $x$ and $y$ denote the horizontal Cartesian coordinate; $z$ expresses the vertical coordinate with positive upward; $u, v$, and $w$ represent the velocity components in the $x, y$, and $z$ directions, respectively; $t$ is time; $f$ denotes Coriolis factor; $g$ expresses the acceleration of gravity; $\eta$ represents the free-surface elevation; $\rho_{0}$ is the reference water density; $\rho$ denotes the water density which considers the effects of water temperature $(T)$ and hydrostatic pressure $(p) ; p_{a}$ is the atmospheric pressure at the free surface; $K_{m x}, K_{m y}$, and $K_{m z}$ represent the eddy viscosity coefficients in $x, y$, and $z$ directions, respectively; $C$ denotes the water quality-ecological state variables; and $K_{c x}, K_{c y}$, and $K_{c z}$ express the turbulent diffusivities in the $x, y$, and $z$ directions, respectively.

The turbulence closure of SCHISM employs the generic length-scale model of Umlauf and Burchard [37] with the stability function of Kantha and Clayson [38]. Since the cross-scale, semi-implicit scheme is adopted in SCHISM, the model allows large time steps supported by lower- and higher-order numerical methods [39]. Wetting and drying processes and a quadratic bottom drag equation for bottom stress are also considered in the model. A detailed description regarding the numerical solution methods, horizontal and vertical grids, and boundary conditions can be found in Zhang et al. [34,35].

SCHISM has been widely utilized in various research fields [18,39-48], but limited cases have been utilized to simulate the hydrodynamics in lakes. Therefore, SCHISM was coupled with an ecological model to develop a hydrodynamic-ecological model (i.e., SCHISM-Ecol) for exploring the planktonic biomass in a subalpine lake. 


\subsection{Phytoplankton and Zooplankton Modules}

The kinetic equation in the mass balance transport equation can be written as

$$
\frac{\partial C}{\partial t}=K C+R
$$

where $K$ denotes the kinetic rate $\left(\right.$ time $\left.^{-1}\right)$ and $R$ expresses the source/sink term (mass volume $^{-1}$ time $^{-1}$ ).

Phytoplankton can be divided into two state variables: periphyton and drifting phytoplankton, which include green algae, diatoms, and others. The subscript, $i$, is employed to represent these two groups. The kinetic equations for phytoplankton biomass can be expressed as

$$
\frac{\partial P B_{i}}{\partial t}=\left(G P_{i}-B M P_{i}-P R P_{i}\right) \cdot P B_{i}+\frac{\partial}{\partial z}\left(W S_{i} \cdot P B_{i}\right)+\frac{W P B_{i}}{V}
$$

where $P B$ denotes the phytoplankton biomass (mass volume ${ }^{-1}$ ); GP represents the production rate of phytoplankton (time ${ }^{-1}$ ); $B M P$ expresses the basal metabolism rate of phytoplankton (time $\left.{ }^{-1}\right) ; P R P$ represents the predation rate on phytoplankton $\left(\right.$ time $\left.^{-1}\right)$. It denotes the rate that the phytoplankton is preyed on by zooplankton; WS is the settling velocity (Length time ${ }^{-1}$ ); WPB denotes the external loads of phytoplankton (mass time ${ }^{-1}$ ); and $V$ expresses the cell volume (volume).

Since copepods frequently appear during winter and summer seasons in TFL, the zooplankton is divided into two state variables: copepods and other species. The subscript, $j$, is employed to represent these two groups. The kinetic equation for zooplankton biomass can be written as

$$
\frac{\partial Z B_{j}}{\partial t}=\left(G Z_{j}-B M Z_{j}-P R Z_{j}\right) \cdot Z B_{j}+\frac{W Z B_{j}}{V}
$$

where $Z B$ denotes the zooplankton biomass (mass volume ${ }^{-1}$ ); $G Z$ expresses the production rate of zooplankton (time ${ }^{-1}$ ); $B M Z$ represents the basal metabolism of zooplankton $\left(\right.$ time $\left.^{-1}\right)$; PRZ indicates the death rate of zooplankton (time ${ }^{-1}$ ); and WZB is the external load of zooplankton (mass time ${ }^{-1}$ ).

Figure 2 illustrates the schematic diagram of water quality-ecological state variables. In the figure, the state variables $\mathrm{DOC}, \mathrm{DON}, \mathrm{DOP}, \mathrm{NH}_{4}, \mathrm{NO}_{3}, \mathrm{PO}_{4}, \mathrm{DO}$, and COD represent dissolved organic carbon, dissolved organic nitrogen, dissolved organic phosphorus, ammonium nitrogen, nitrate nitrogen, orthophosphate, dissolved oxygen, and chemical oxygen demand, respectively. Fecal coliform and fish biomass are also included in the model simulation.

\subsection{Model Setups}

To build unstructured grids (triangles) for numerical simulation, bathymetric TFL data were collected from Academia Sinica in Taiwan. Surface-water modeling system (SMS) software was utilized to build unstructured grids and to greatly reduce the time for manual grid generation. In the horizontal plane, a total of 11,589 unstructured grids were generated for model simulation. The grid size is approximately $5 \mathrm{~m}$. A pure $\mathrm{S}$ coordinate was utilized with 5 S-levels in the vertical plane (see Figure 3). A time step ( $\Delta t=120 \mathrm{~s}$ ) was used in the hydrodynamic-ecological model simulations. A constant bottom roughness height, $\mathrm{z}_{\mathrm{O}}=0.001 \mathrm{~m}$, was adopted in the modeling. A 60-day spin-up time was utilized to achieve an equilibrium condition. 


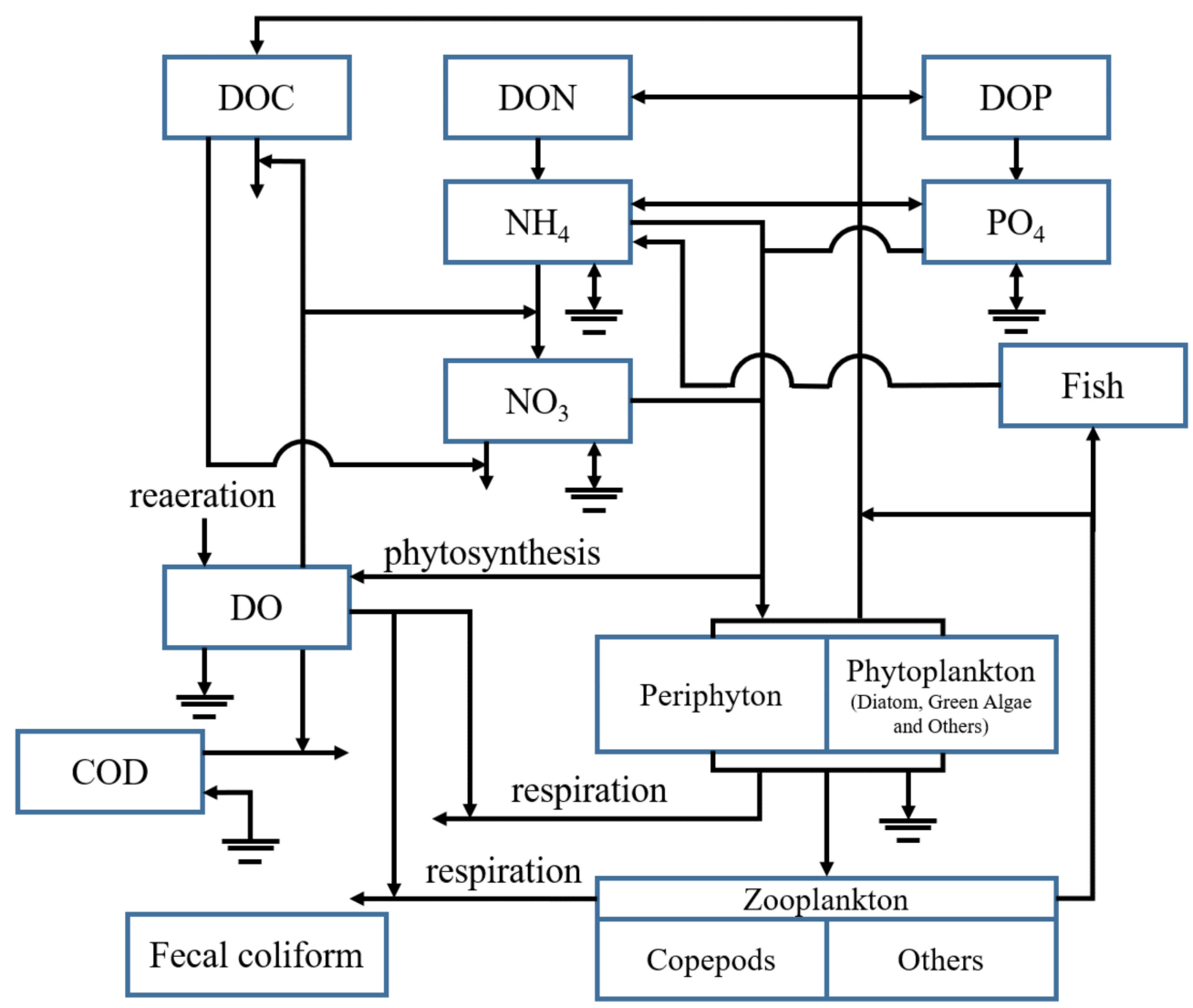

Figure 2. Schematic diagram of the water quality-biological interactions among the state variables.

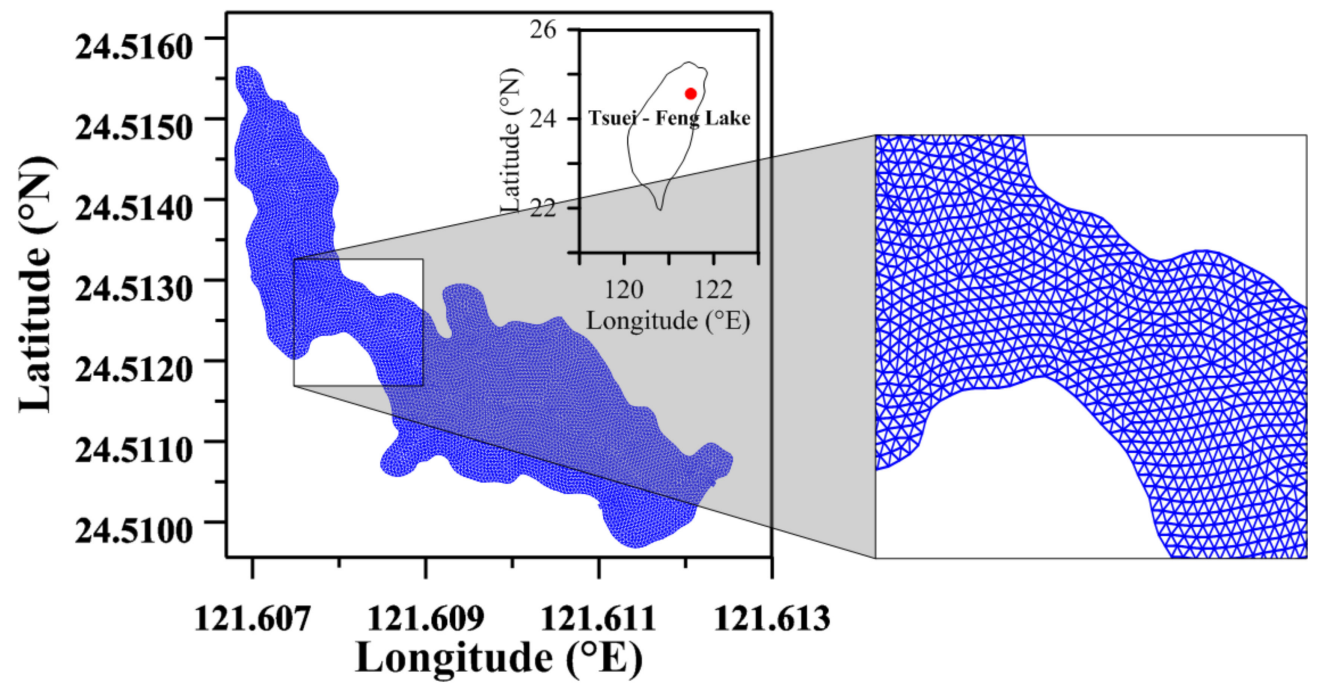

Figure 3. Unstructured grids used for the hydrodynamic-ecological modeling of Tsuei-Feng Lake.

\subsection{Statistical Error for Model Performance}

Three statistical indexes consisting of the mean absolute error (MAE), the Pearson correlation coefficient (CC), and the predictive skill (skill) were employed to quantify the model performance of SCHISM-Ecol. Model validation to compare the model results with observational data can achieve the minimization of MAE and the maximization of $r$ (within positive range) and skill value. Equations (9) and (11) for MAE, CC, and skill [49] can be expressed as

$$
\frac{\partial Z B_{j}}{\partial t}=\left(G Z_{j}-B M Z_{j}-P R Z_{j}\right) \cdot Z B_{j}+\frac{W Z B_{j}}{V}
$$




$$
\begin{gathered}
C C=\frac{\sum_{i=1}^{N}\left(C_{m}^{i}-\overline{C_{m}}\right)\left(C_{o}^{i}-\overline{C_{o}}\right)}{\sqrt{\sum_{i=1}^{N}\left(C_{m}^{i}-\overline{C_{m}}\right)^{2} \sum_{i=1}^{N}\left(C_{o}^{i}-\overline{C_{o}}\right)^{2}}} \\
\text { skill }=\frac{\sum_{i=1}^{N}\left|C_{m}^{i}-C_{o}^{i}\right|^{2}}{\sum_{i=1}^{N}\left(\left|C_{m}^{i}-\overline{C_{o}}\right|+\left|C_{o}^{i}-\overline{C_{o}}\right|\right)^{2}}
\end{gathered}
$$

where $N$ represents the total number of modeled/observed data; $C_{m}^{i}$ denotes the modeled value at data point i; $C_{o}^{i}$ expresses the observed value at data point $i ; \overline{C_{m}}=\frac{1}{N} \sum_{i=1}^{N} C_{m}^{i} ;$ and $\overline{C_{o}}=\frac{1}{N} \sum_{i=1}^{N} C_{o}^{i}$.

The MAE denotes the average deviation between the simulation and measurement. The Pearson correlation coefficient (CC) was employed to detect the linear relationship between the modeled results and measured data. The $r$ value is in the range between +1 and -1 to denote a positive and negative relationship, respectively. If $r=0$, no relationship exists. A predictive skill equal to 1 denotes perfect agreement of the model-measurement relationship, while a predictive skill equal to 0 expresses complete disagreement of the model measurement $[45,50]$.

\subsection{Metric for Sensitivity Analysis}

Sensitivity analysis is an important procedure to understand which parameters affect the simulation results. To quantify the results of parameter sensitivity analysis, the maximum rate is adopted in this study. The equation to express the maximum rate $(M R)$ is shown as

$$
M R=\frac{C_{\text {baseline }}-C_{\text {sen }}}{C_{\text {baseline }}} \times 100 \%
$$

where $C_{b}$ denotes the phytoplankton and zooplankton biomass for the baseline simulation and $C_{S}$ represents the phytoplankton and zooplankton biomass for the sensitivity run.

\section{Model Validation}

The measured data, including water depth, water temperature, and water qualityecological state variables, were gathered from September 2017 to July 2018 to quantify the model accuracy for validating SCHISM-Ecol. Since the spin-up time of the model was set to 60 days, the model was conducted starting on 1 July 2017. The initial conditions for water depth and water temperature were specified as $1.5 \mathrm{~m}$ and $20^{\circ} \mathrm{C}$, respectively. The mean values of measured water quality and ecological variables were set as the initial conditions for simulating the SCHISM-Ecol model.

\subsection{Water Depth}

To precisely predict the water depth of the TFL, in this study, the daily discharges at the inflow and outflow locations in the lake served as an input to drive the model simulation for predicting the time-series water depth.

Figure 4a depicts the time-series inflow and outflow discharges in the TFL. Due to the multiple heavy rainfalls and Typhoon Khanun, several peak inflow discharges occurred during the periods of October 11 and 15. Based on the recorded data, the total rainfall during the periods was $1023.7 \mathrm{~mm}$. Figure $4 \mathrm{~b}$ illustrates the comparison between simulated and observed time-series water depths from 1 September 2017, to 31 July 2018, indicating that the high inflow discharges quickly responded to the high water depth in the lake. However, the simulated results reproduced the observed water depths well. It also indicated that the peak water depth reached $10.13 \mathrm{~m}$ at 7:00 am on 16 October 2017 (Figure $4 \mathrm{~b}$ ). It also showed that the model reproduced the observed normal and low water depths well. The values for MAE, CC, and skill were $0.03 \mathrm{~m}, 0.92$, and 0.95 , respectively. Based on the model-data comparison, excellent model performance was achieved. 

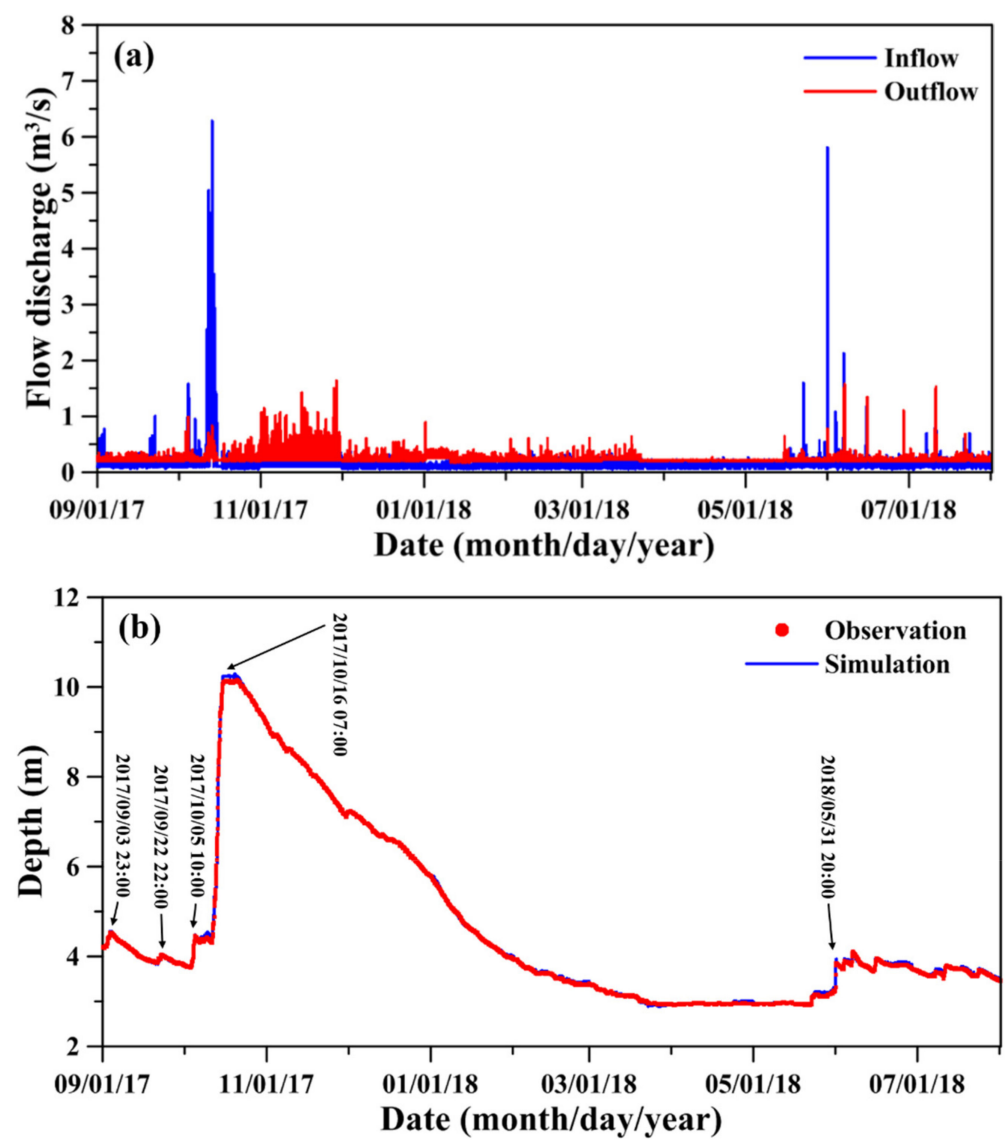

Figure 4. (a) Time-series inflow and outflow discharges from 1 September 2017 to 31 July 2018, and (b) the comparison of water depth between observation and simulation.

\subsection{Water Temperature}

The precise prediction of water temperature in lakes is a crucial requirement for modeling water quality-ecological state variables and further water quality management. To validate the 3D coupled model, the measured water temperature data at the buoy station gathered from 1 September 2017, to 31 July 2018, were utilized for comparison with the modeling results. Meteorological data were employed to calculate heat and momentum fluxes, providing the surface boundary condition for the 3D coupled model.

Figure 5 compares the simulated water temperatures in the time series and measured results. The water temperature at $0.5 \mathrm{~m}$ below the water surface displayed day-night variations. The water temperature reached $22.2{ }^{\circ} \mathrm{C}$ during the summer but decreased to $4.1^{\circ} \mathrm{C}$ during the winter. The water temperature during the daytime was higher than the nighttime temperature. This figure also indicated that the simulated water temperatures accurately reproduced the measured results. The values of MAE, CC, and skill were $0.29^{\circ} \mathrm{C}$, 0.96 , and 0.98 , respectively, between the simulated and observed water temperatures. The comparison of the observed and simulated water temperatures in vertical profiles at the buoy station is illustrated in the Supplementary Materials (Table S1). This result indicated that the simulated results satisfactorily reproduced the observed vertical water temperature on different dates, except for the measured dates on 5 September 2017. The simulated water temperatures exhibited more vertical mixing at the bottom layers than the observational data on 5 September 2017. This would be the reason that the stronger turbulent mixing in the vertical direction was calculated by the model. 


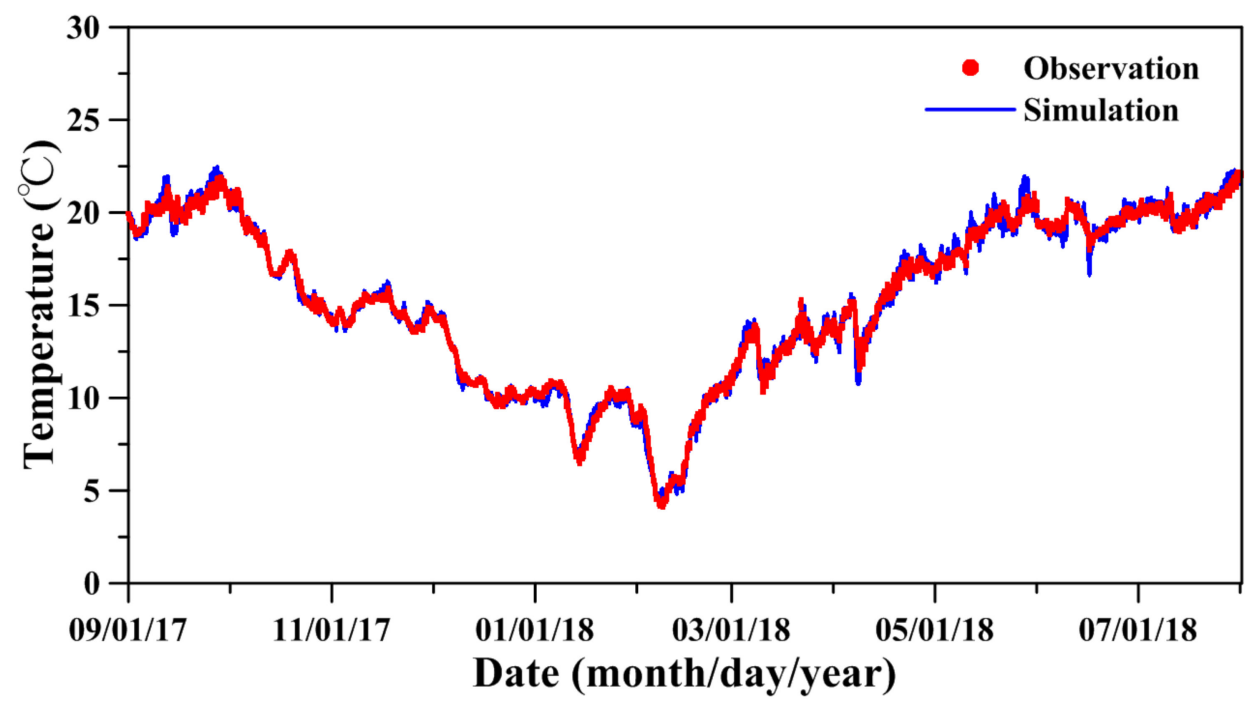

Figure 5. Comparison between simulated and measured water temperatures with time series.

Table 1 presents the statistical errors of the comparison between the simulated and observed water temperatures in the vertical profile on different measured dates. The computed water temperatures in the vertical profile satisfactorily matched the measured results during the summer and winter seasons but slightly underestimated the measured results in the bottom layer in September 2017. Based on the skill values, the model performance in the vertical profiles ranged between very good and excellent scores.

Table 1. Statistical errors based on differences between simulated and measured water temperatures.

\begin{tabular}{cccc}
\hline Year/Month/Date & MAE $\left({ }^{\circ} \mathbf{C}\right)$ & $C C$ & Skill \\
\hline $2017 / 09 / 05$ & 0.58 & 0.96 & 0.60 \\
$2017 / 10 / 10$ & 0.40 & 0.78 & 0.66 \\
$2017 / 11 / 21$ & 0.18 & 0.91 & 0.56 \\
$2018 / 01 / 09$ & 0.10 & 0.80 & 0.79 \\
$2018 / 03 / 26$ & 0.24 & 0.94 & 0.91 \\
$2018 / 05 / 15$ & 0.86 & 0.68 & 0.66 \\
$2018 / 06 / 12$ & 0.90 & 0.78 & 0.86 \\
$2018 / 07 / 17$ & 0.15 & 0.98 & 0.99 \\
\hline
\end{tabular}

\subsection{Water Quality and Ecology}

To ensure that the water quality and planktonic modules in the SCHISM-Ecol model are reliable and predictive, the measured water quality and ecological variable data were employed to validate the coupled model.

Several reports have documented that the validation of water quality-ecological models is more difficult than that of hydrodynamic models since there are many parameters to be adjusted and determined in water quality-ecological models [15,51-54]. Fortunately, values for these parameters have been reported [55-60] and can be adjusted and adopted in this study. The trial-and-error method for validating the water quality-ecological model is utilized.

Figure 6 compares the measured and simulated DO, DOC, $\mathrm{NH}_{4}, \mathrm{DON}, \mathrm{PO}_{4}, \mathrm{DOP}$, phytoplankton biomass, and zooplankton biomass. The simulated water quality-ecological state variables quantitatively agreed with the measured data. The model results depicted that the phytoplankton and zooplankton biomass was high from May to July. Table 2 shows the statistical errors between the simulated and measured results for the water quality-ecological state variables. The predictive skill and correlation coefficient are all above 0.86. Excellent model performance is achieved when the skill value exceeds 0.90 . The parameters adopted in the water quality-ecological model are displayed in the Supplementary Materials (Table S1). 

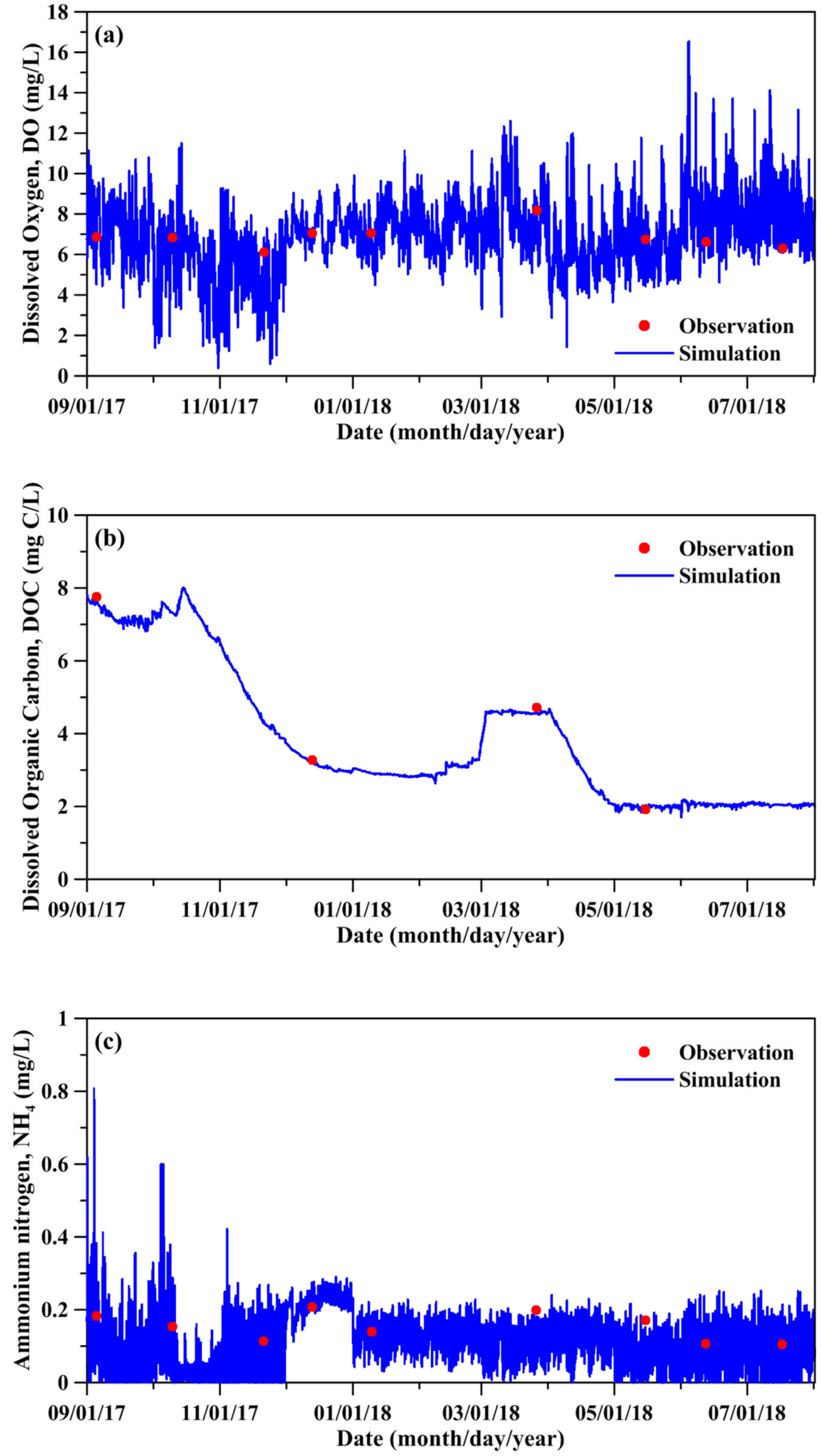

Figure 6. Cont. 

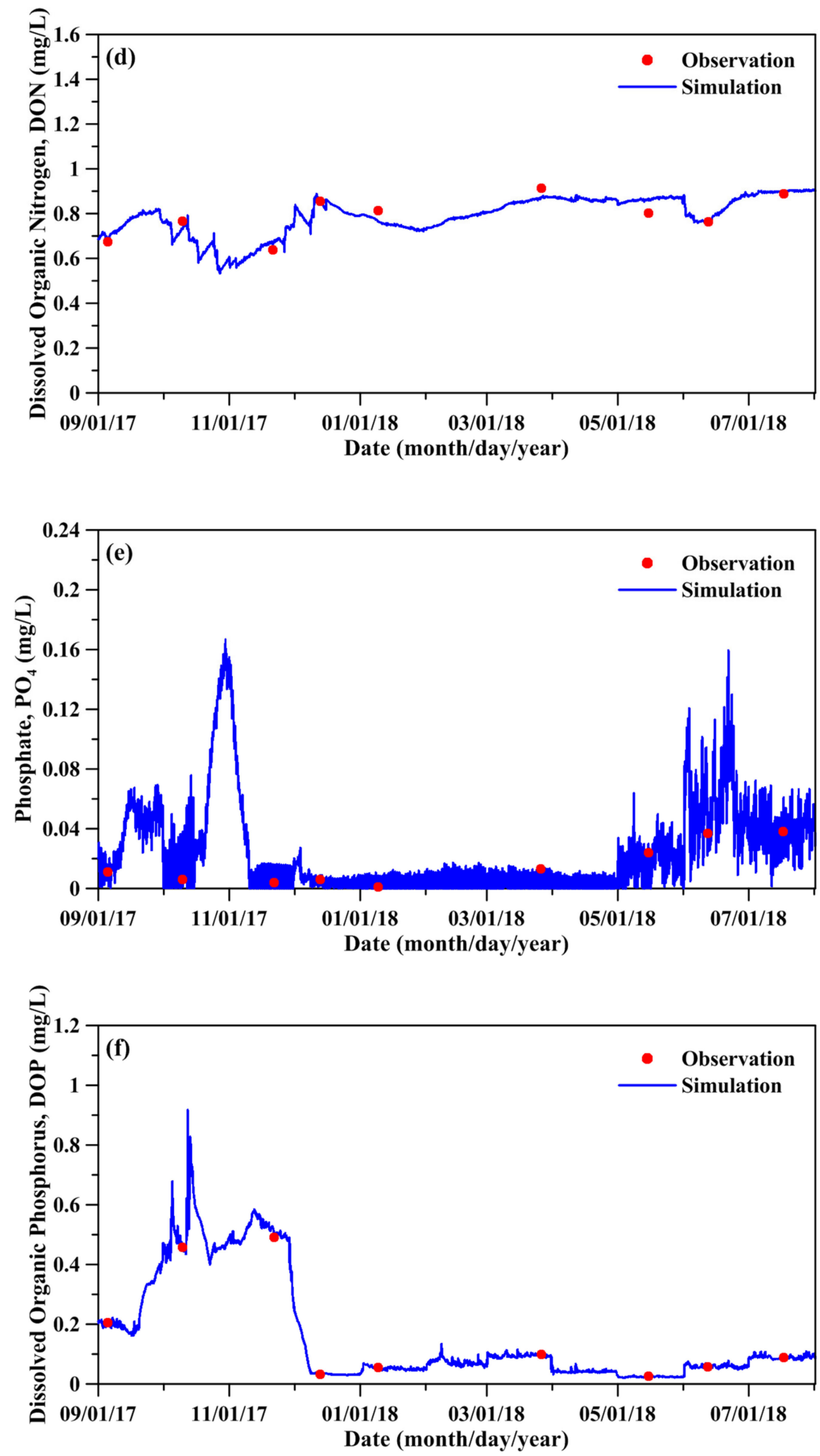

Figure 6. Cont. 

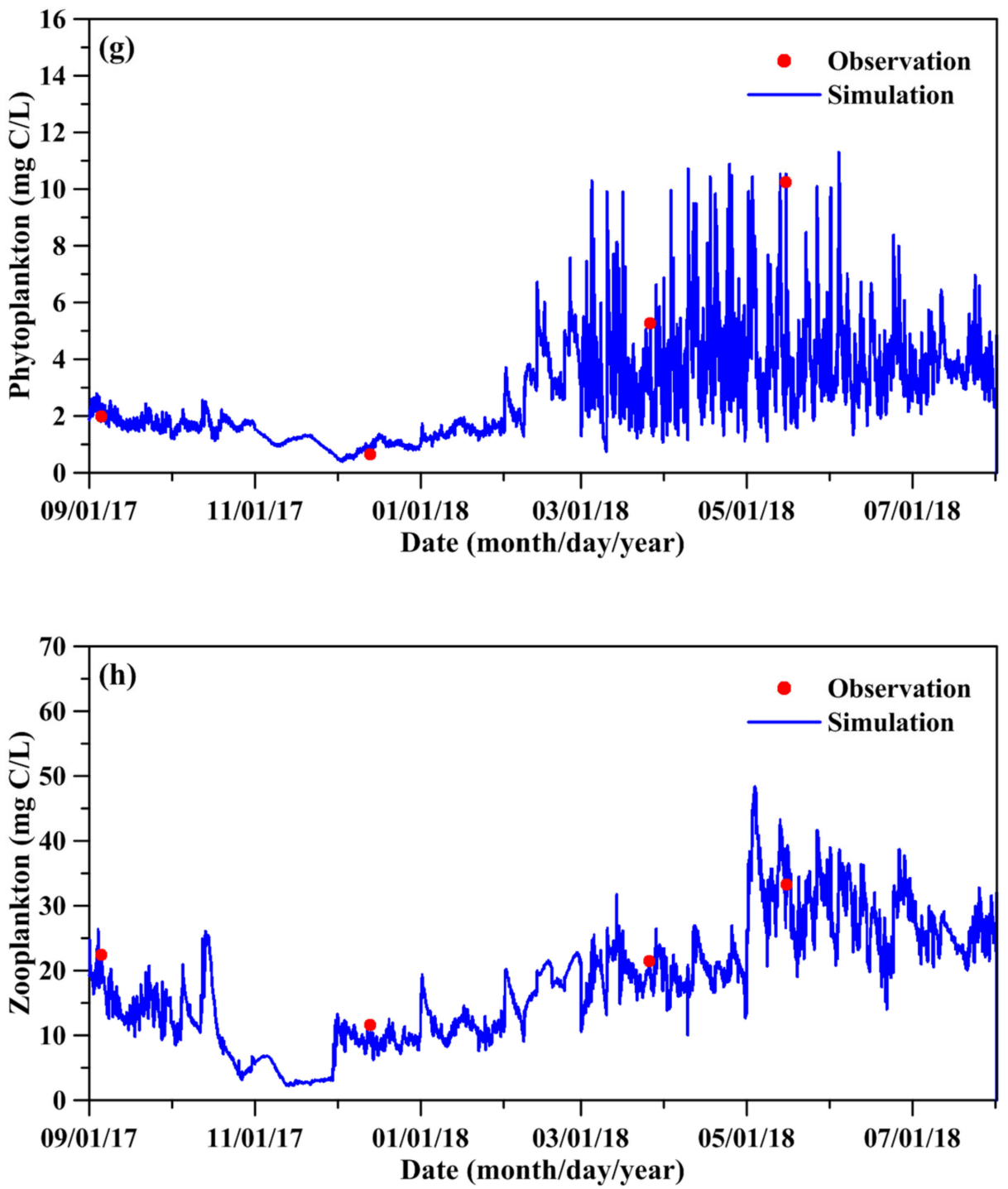

Figure 6. Comparison between simulated and measured water quality and planktonic biomass: (a) DO, (b) DOC, (c) $\mathrm{NH}_{4}$, (d) DON, (e) $\mathrm{PO}_{4}$, (f) DOP, (g) phytoplankton, and (h) zooplankton.

Table 2. Statistical error based on differences between simulated and measured water qualityecological state variables.

\begin{tabular}{cccc}
\hline State Variable & $\begin{array}{c}\text { MAE (Unit in } \\
\text { State Variable) }\end{array}$ & CC & Skill \\
\hline $\mathrm{DO}(\mathrm{mg} / \mathrm{L})$ & 0.22 & 0.87 & 0.92 \\
$\mathrm{DOC}(\mathrm{mg} \mathrm{C} / \mathrm{L})$ & 0.08 & 0.98 & 0.95 \\
$\mathrm{NH}_{4}(\mathrm{mg} / \mathrm{L})$ & 0.02 & 0.86 & 0.90 \\
$\mathrm{DON}^{(\mathrm{mg} / \mathrm{L})}$ & 0.03 & 0.93 & 0.96 \\
$\mathrm{PO}_{4}(\mathrm{mg} / \mathrm{L})$ & 0.002 & 0.99 & 0.91 \\
$\mathrm{DOP}(\mathrm{mg} / \mathrm{L})$ & 0.005 & 0.96 & 0.96 \\
Phytoplankton biomass & 0.16 & 0.99 & 0.95 \\
(mg C/L) & 0.96 & 0.99 & 0.95 \\
Zooplankton biomass & & & \\
(mg C/L) & &
\end{tabular}




\section{Results and Discussion}

\subsection{Sensitivity Analysis of Phytoplankton and Zooplankton Biomass}

Furthermore, the validated model was utilized to implement sensitivity analysis to explore how the parameters adopted in the planktonic module affected phytoplankton and zooplankton biomass. The parameters used for sensitivity analysis were GP, BMP, PRP, and WS for phytoplankton and GZ, BMZ, and PRZ for zooplankton. Even though basal metabolism is an inalienable and stable parameter of an organism, the parameter is also adjusted to understand how it affects the simulation result.

The model validation from September 2017 to July 2018 served as the baseline. Two alternative scenarios were employed to investigate the effect of planktonic parameters on the biomass of phytoplankton and zooplankton. They are the planktonic parameters plus 50\% and minus $50 \%$ based on the parameters used for model validation.

Figure 7 illustrates the model sensitivity results for the most important parameters, which are the predation rate on phytoplankton (PRP) and basal metabolism rate of zooplankton (BMZ), affecting the phytoplankton biomass and zooplankton biomass from 11 July to 20 July 2018 . When the PRP was reduced by $50 \%$, the phytoplankton biomass was most affected (Figure 7a), while when the BMZ was decreased by $50 \%$, the zooplankton biomass was most affected (Figure $7 \mathrm{~b}$ ). Table 3 lists the results of sensitivity runs for different planktonic parameters. This result shows that an increase in PRP and BMZ parameters results in a decrease in phytoplankton and zooplankton biomass. The maximum rates for increasing and decreasing phytoplankton biomass referred to the PRP parameter were $157.12 \%$ and $44.36 \%$, respectively, while the maximum rates for increasing and decreasing zooplankton biomass related to the BMZ parameter were $62.54 \%$ and $28.74 \%$, respectively.
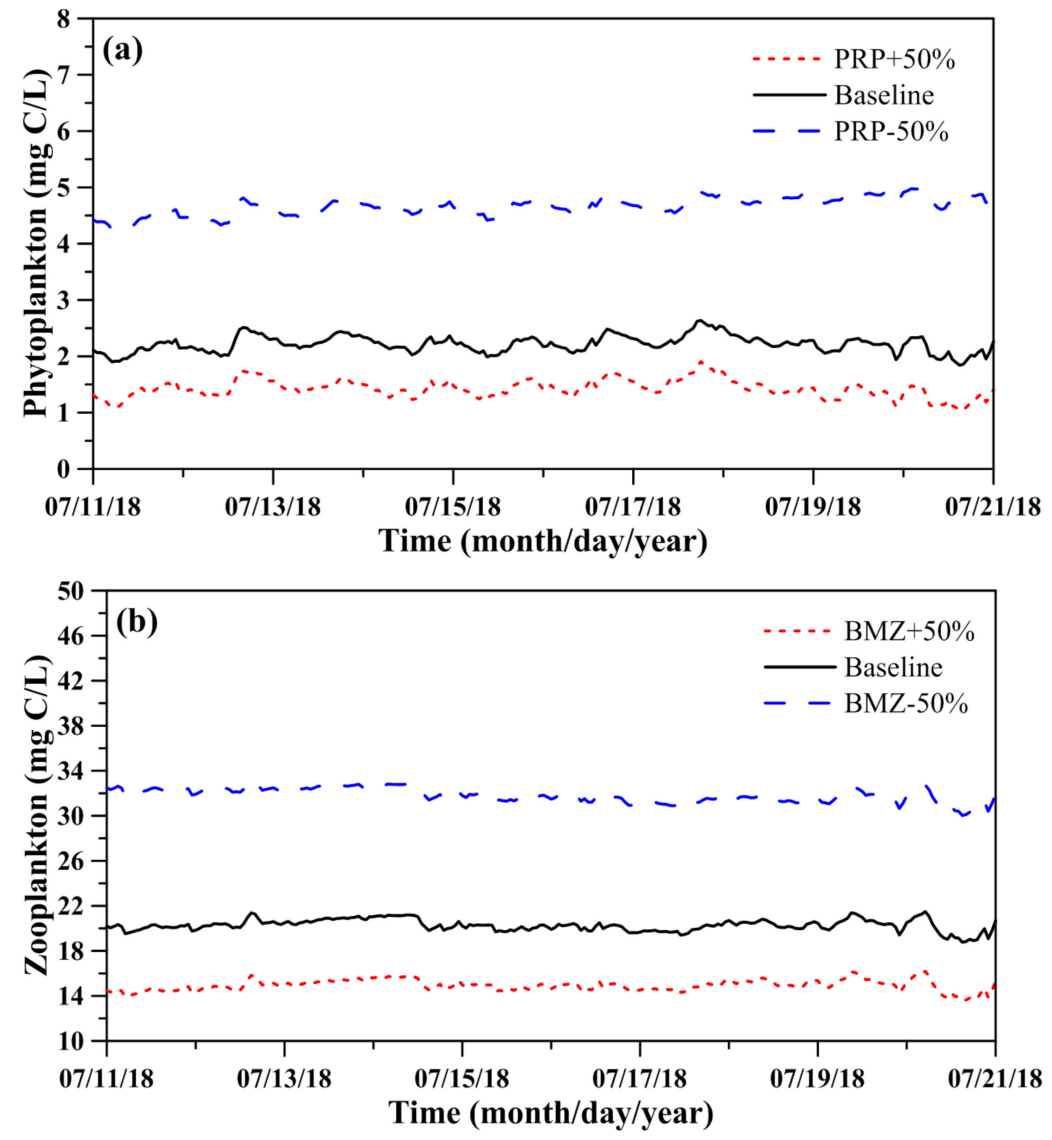

Figure 7. Model sensitivity for the (a) influence of predation rate on phytoplankton (PRP) on phytoplankton biomass and for the (b) influence of basal metabolism rate of zooplankton (BMZ) on zooplankton biomass. 
Many parameters existed in the water quality-ecological model to be tuned. Most studies have shown the parameters only but have not implemented sensitivity analysis for parameters $[15,30,61,62]$. However, there are few parameters in the planktonic model, so the procedure for performing sensitivity analysis of parameters is not too cumbersome. According to the sensitivity analysis of parameters in the planktonic model, we found that the predation rate on phytoplankton (PRP) and basal metabolism rate of zooplankton (BMZ) were the most crucial parameters to be fine-tuned in the TFL.

Table 3. Results of sensitivity analysis for phytoplankton and zooplankton parameters.

\begin{tabular}{|c|c|c|c|}
\hline Parameter & Condition & Phytoplankton (\%) & Zooplankton (\%) \\
\hline Growth rate of & $+50 \%$ & 8.67 & -0.08 \\
\hline phytoplankton (GP) & $-50 \%$ & -21.80 & 0.51 \\
\hline \multirow{2}{*}{$\begin{array}{c}\text { Basal metabolism rate of } \\
\text { phytoplankton (BMP) }\end{array}$} & $+50 \%$ & -0.73 & 0.03 \\
\hline & $-50 \%$ & 0.72 & -0.02 \\
\hline \multirow{2}{*}{$\begin{array}{c}\text { Predation rate on } \\
\text { phytoplankton (PRP) }\end{array}$} & $+50 \%$ & -44.36 & 1.96 \\
\hline & $-50 \%$ & 157.12 & -5.12 \\
\hline \multirow{2}{*}{$\begin{array}{c}\text { Settling velocity of } \\
\text { phytoplankton (WS) }\end{array}$} & $+50 \%$ & -0.13 & -0.01 \\
\hline & $-50 \%$ & 0.13 & 0.01 \\
\hline \multirow{2}{*}{$\begin{array}{c}\text { Growth rate of } \\
\text { zooplankton }(\mathrm{GZ})\end{array}$} & $+50 \%$ & -28.05 & 28.43 \\
\hline & $-50 \%$ & 55.03 & -28.34 \\
\hline \multirow{2}{*}{$\begin{array}{c}\text { Basal metabolism rate of } \\
\text { zooplankton (BMZ) }\end{array}$} & $+50 \%$ & 52.10 & -28.74 \\
\hline & $-50 \%$ & -41.98 & 62.54 \\
\hline \multirow{2}{*}{$\begin{array}{c}\text { Mortality rate of } \\
\text { zooplankton (PRZ) }\end{array}$} & $+50 \%$ & 0.34 & -0.26 \\
\hline & $-50 \%$ & -0.34 & 0.26 \\
\hline
\end{tabular}

Note: Minus and plus denote decreasing and increasing planktonic biomass, respectively.

\subsection{Effect of Water Temperature and Inflow on Phytoplankton and Zooplankton Biomass}

We suppose that environmental variations, including water temperature and inflow, would be dominant factors affecting planktonic biomass. Furthermore, the validated model was employed to probe the influence of environmental variables on phytoplankton and zooplankton biomass of TFL. Three scenarios were implemented to determine the main purpose of this section.

The first scenario was enacted to alter inflow discharge to cover a strong rainfall intensity-induced high inflow discharge into the lake. In this scenario run, the normal inflow was set to $0.1 \mathrm{~m}^{3} / \mathrm{s}$, and inflow phytoplankton biomass, zooplankton biomass, and average water temperature were specified as $9.0 \mathrm{mg} \mathrm{C} / \mathrm{L}, 35.1 \mathrm{mg} \mathrm{C} / \mathrm{L}$, and $15.2^{\circ} \mathrm{C}$. The artificial inflow hydrograph is illustrated in Figure 8. It clearly shows that the inflow discharge reached the maximum value $\left(=6.3 \mathrm{~m}^{3} / \mathrm{s}\right)$ at the $127 \mathrm{th}$. The second scenario run was set to alter the inflow water temperature to the summer temperature, which was $20.4{ }^{\circ} \mathrm{C}$, while keeping the normal inflow discharge at $0.1 \mathrm{~m}^{3} / \mathrm{s}$. The third scenario run was specified with the inflow water temperature using winter temperature, which was $7.8^{\circ} \mathrm{C}$ and kept the same inflow discharge as the second scenario run. The model was implemented in a one-month simulation to yield the planktonic biomass.

Figure 9 depicts the comparison of calculated phytoplankton biomass at the buoy station under the three scenarios. The phytoplankton biomass was significantly affected by inflow discharge and reached a maximum of $6.7 \mathrm{mg} \mathrm{C} / \mathrm{L}$ at the 134th hour in TFL but exhibited little effect by inflow water temperature. Figure 10 illustrates the distribution of phytoplankton biomass at the surface layer at the 134th hour. Figure 10a indicates that the phytoplankton biomass near the inflow was approximately $2.5 \mathrm{mg} \mathrm{C} / \mathrm{L}$, and the biomass at other positions was less than $2.0 \mathrm{mg} \mathrm{C} / \mathrm{L}$ for the baseline case. Figure $10 \mathrm{~b}$ shows that the biomass near the inflow reached $7.5 \mathrm{mg} \mathrm{C} / \mathrm{L}$, and the minimum value was approximately $3.5 \mathrm{mg} \mathrm{C} / \mathrm{L}$ at the northeast side of TFL since the inflow discharge was changed. Figure 10c displays the phytoplankton biomass difference between the changing inflow discharge scenario run and the baseline run. This reveals that the phytoplankton biomass increased 
in the lake, and the biomass near the outflow location increased the most, by approximately $5.0 \mathrm{mg} \mathrm{C} / \mathrm{L}$.

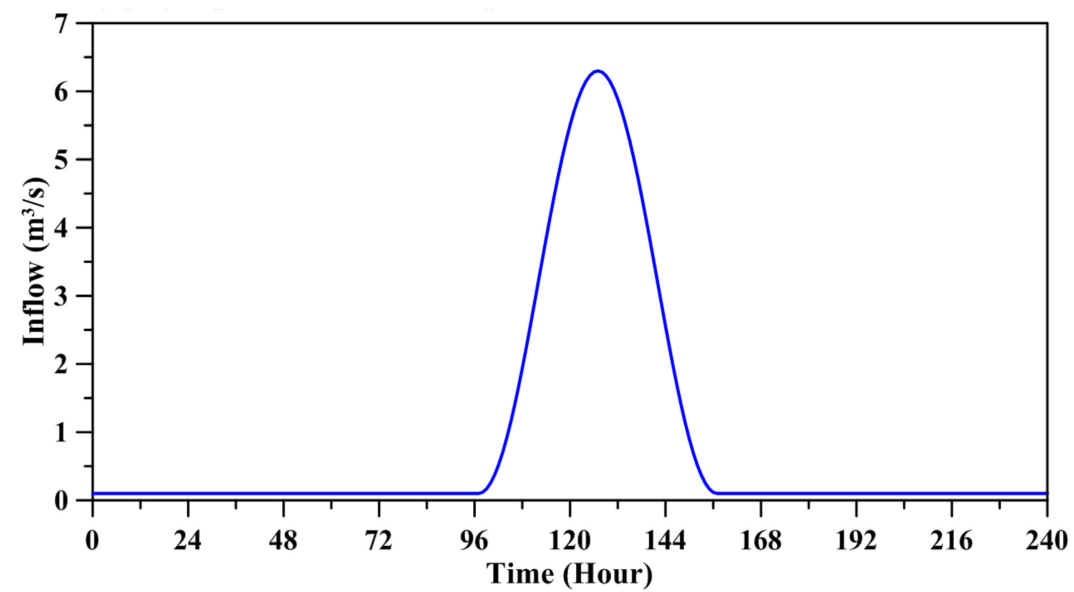

Figure 8. Artificial inflow hydrograph for simulating the change in discharge scenario.

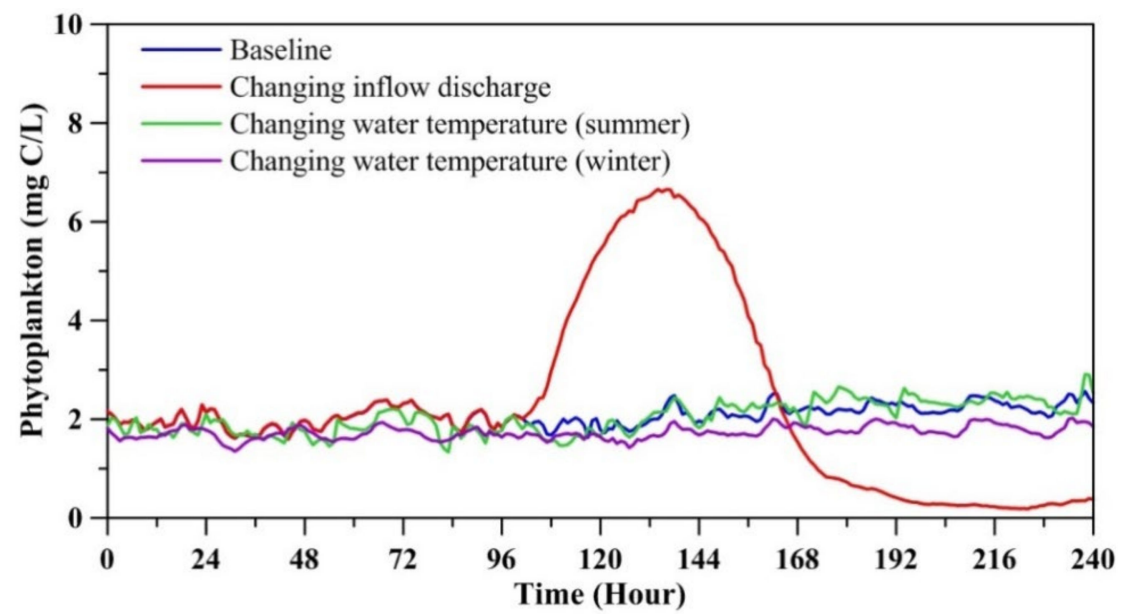

Figure 9. Comparison of calculated phytoplankton biomass for three scenario runs.

Figure 11 delineates the comparison of calculated zooplankton biomass at the buoy station for the three scenario runs. This result indicates that the inflow discharge crucially affected the zooplankton biomass, reaching a maximum of $48.7 \mathrm{mg} \mathrm{C} / \mathrm{L}$ at the 155th hour and then recovering to biomass of $24.0 \mathrm{mg} \mathrm{C} / \mathrm{L}$. It can be noted that the time for phytoplankton and zooplankton biomass to reach the maximum is different due to the fact that when phytoplankton flow into the lake, they serve as food for zooplankton predation, so the time for the maximum biomass of zooplankton is slightly later than that of phytoplankton. The zooplankton biomass under the changing inflow summer water temperature and changing inflow winter water temperature scenario runs was approximately $21.0 \mathrm{mg} \mathrm{C} / \mathrm{L}$ and $24.0 \mathrm{mg} \mathrm{C} / \mathrm{L}$, respectively. 

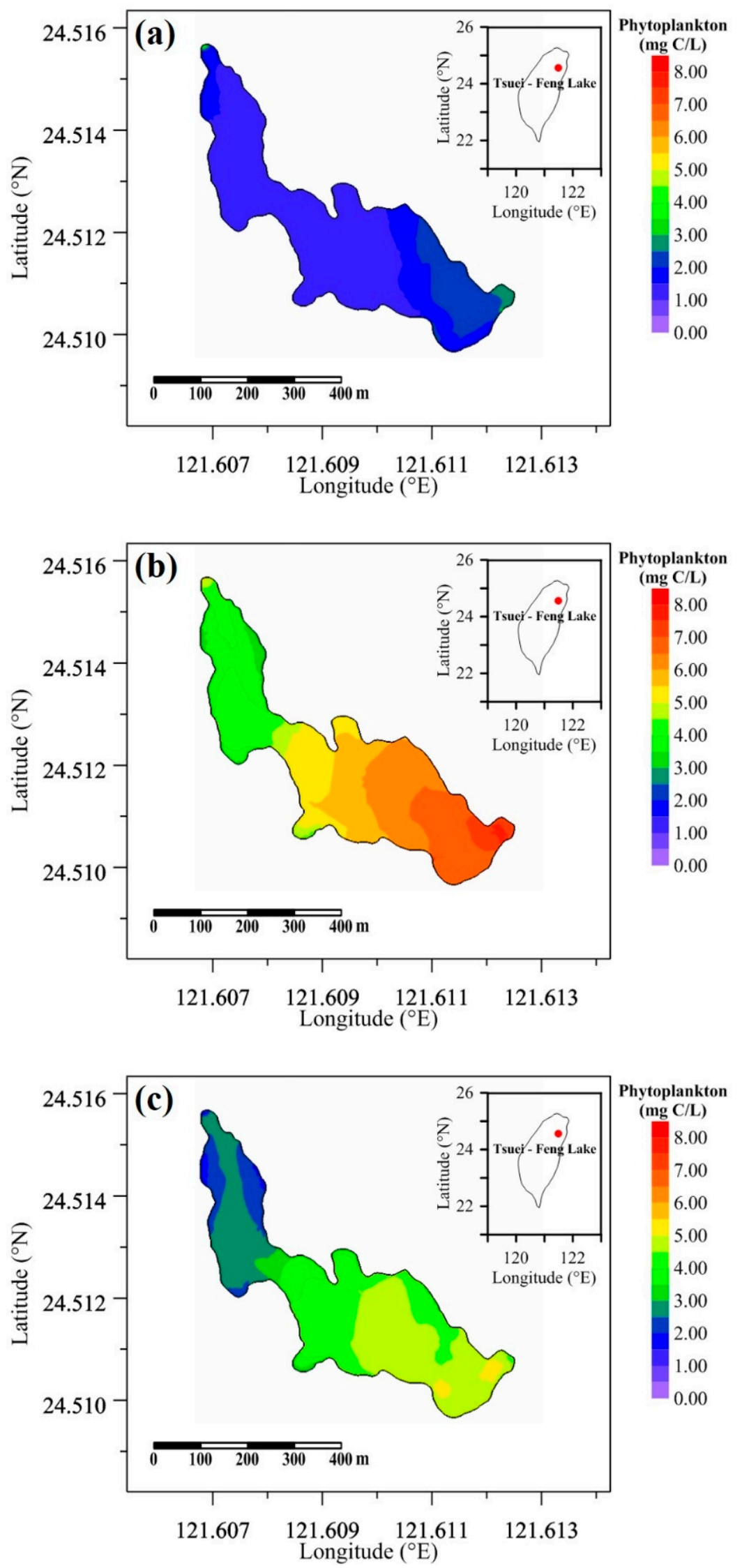

Figure 10. Spatial distributions of phytoplankton biomass for (a) the baseline run, (b) the changing inflow discharge scenario run, and (c) the difference between the changing inflow discharge scenario and baseline runs. 


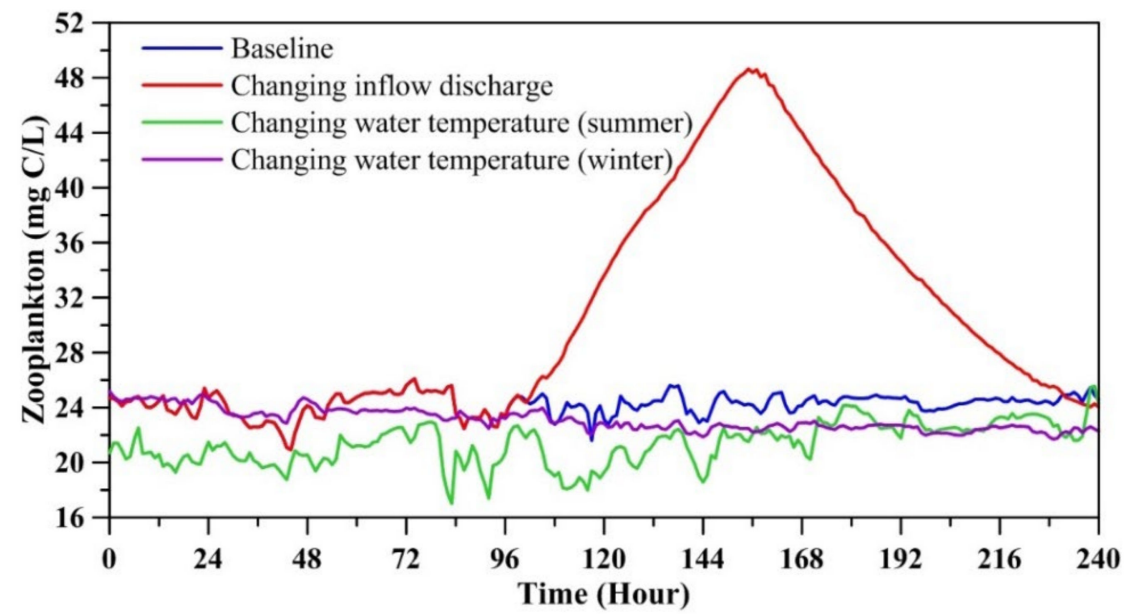

Figure 11. Comparison of calculated zooplankton biomass for three scenario runs.

Figure 12 illustrates the distribution of zooplankton biomass at the surface layer at the 155th hour. Figure 12a shows that the zooplankton biomass near the inflow reaches $25.0 \mathrm{mg} \mathrm{C} / \mathrm{L}$ for the baseline run, and the lower biomass at the outflow side is $14.0 \mathrm{mg} \mathrm{C} / \mathrm{L}$. Figure $12 \mathrm{~b}$ indicates that the zooplankton biomass was higher at the inflow location, reaching $49.0 \mathrm{mg} \mathrm{C} / \mathrm{mg}$, and lower at the outflow location $(=40.0 \mathrm{mg} \mathrm{C} / \mathrm{L})$ under the changing inflow discharge scenario run. Figure 12c shows the zooplankton biomass difference between the changing inflow discharge scenario and the baseline runs. This reveals that the zooplankton biomass increased, and the biomass at the center side of the lake increased the most. Overall, the range of increasing zooplankton biomass was from 8.1 to $29.1 \mathrm{mg} \mathrm{C} / \mathrm{L}$.

The light regime and grazing impact are known to be important drivers of phytoplankton biomass. The same applied to fish predators in the case of zooplankton biomass. However, there are many environmental factors affecting the planktonic biomass in lakes, such as water temperature, land use, and climate change [8,28,63-65]. Environmental change mostly results from anthropogenic impacts [1]. Land use and climate change alter inflow discharge, nutrient loads from watersheds, and water temperature, resulting in changes in ecological status. The results of sensitivity analysis for inflow discharge and thermal alterations indicate that inflow discharge alteration plays the most important role in affecting phytoplankton and zooplankton biomass in the TFL.

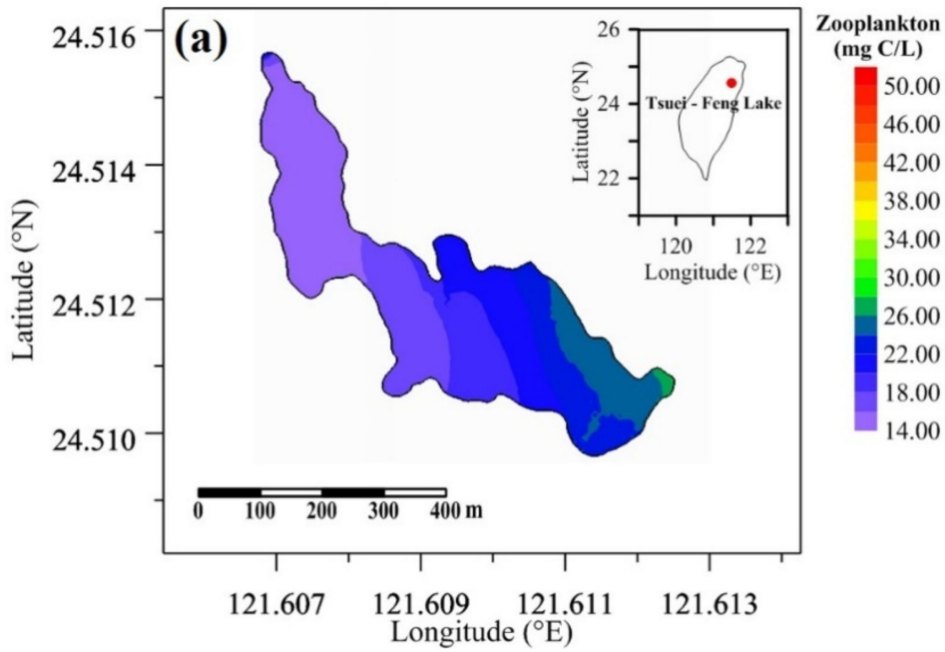

Figure 12. Cont. 

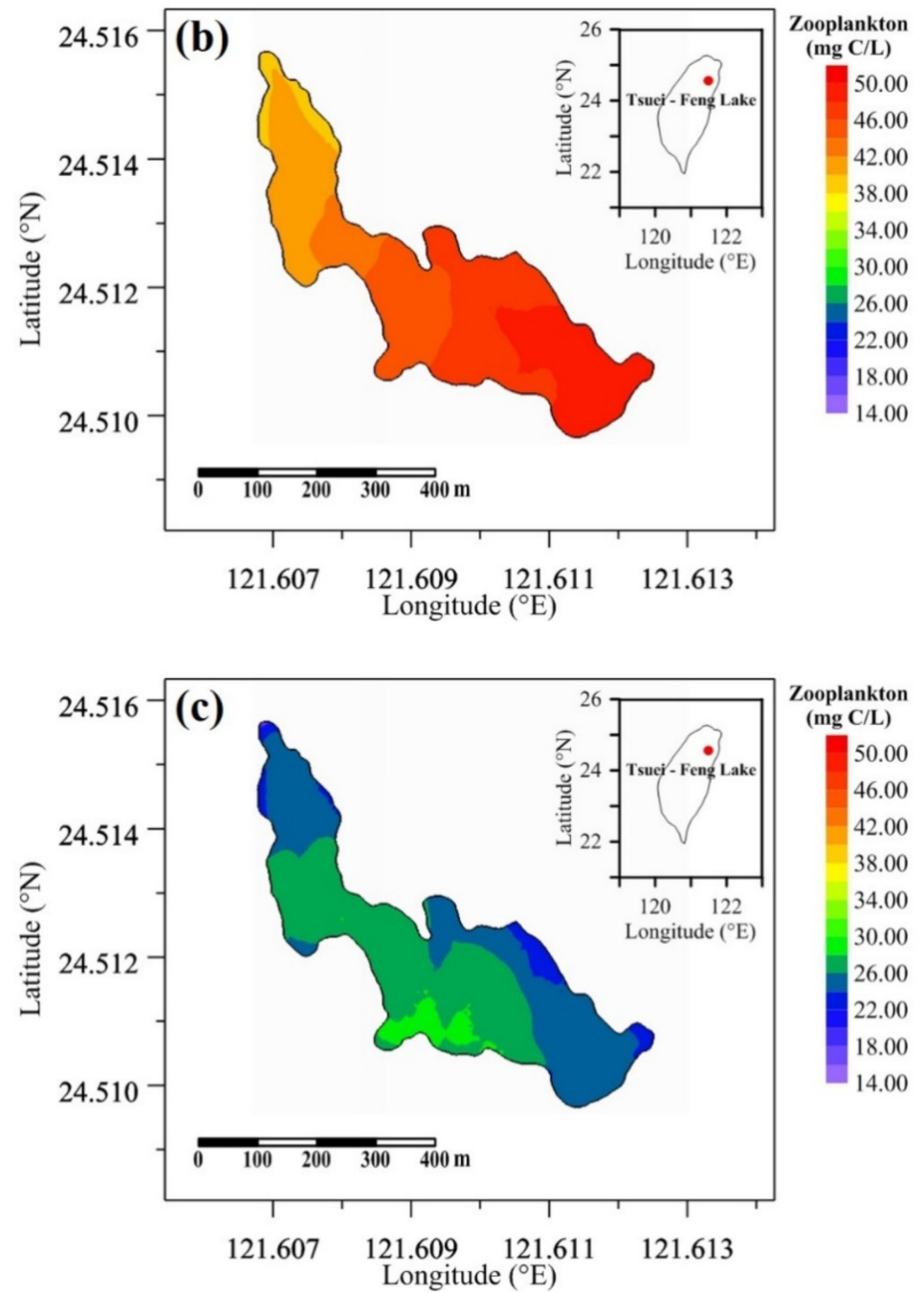

Figure 12. Spatial distributions of zooplankton biomass for (a) the baseline run, (b) the changing discharge scenario run, and (c) the difference between the changing discharge scenario and baseline runs.

\subsection{Limitations}

The current ecological model did not consider intraspecific and interspecific competition in plankton assemblages that might lead to inconsistent results. Moreover, seasonal difference in planktonic communities would be taken into account since tropic structure affects the total biomass of plankton. In the ecological model, the module of fish biomass has been built, but the measured of fish species and biomass were scarce. Therefore, the fish module was not driven to simulate the fish biomass. In addition, the parameters that affect phytoplankton and zooplankton biomass vary in different lakes and must be adapted to local conditions. Therefore, when implementing the ecological model, it is best to have a good understanding of the characteristics of the parameters and to prioritize parameter testing and sensitivity analysis $[66,67]$. Incorrect selection of parameter values may lead to incorrect simulation results.

\section{Conclusions}

A coupling 3D hydrodynamic-ecological model called SCHISM-Ecol was developed and implemented to simulate planktonic biomass in Tsuei-Feng Lake (TFL), Taiwan. The observational data of water depth, water temperature, water quality, and phytoplankton and zooplankton biomass measured in 2017 and 2018 were utilized to validate the coupled 
model. Statistical metrics were used to quantitatively evaluate the modeling results and observed data. The modeling results reasonably reproduced the observations.

The sensitivity analysis was implemented using the validated model to determine which parameter was the most influential factor in dominating planktonic biomass. The results of sensitivity analysis indicated that the predation rate on phytoplankton (PRP) and basal metabolism rate of zooplankton (BMZ) were the crucial influential parameters for phytoplankton and zooplankton biomass, respectively. Moreover, the validated model was employed to prove the impact of environmental variables on planktonic biomass. The modeling results showed that inflow discharge was the most crucial factor subjected to changes in the external environment to affect the phytoplankton and zooplankton biomass of TFL.

Future work on lake studies will focus on the cross-sector cooperation that is needed to gather scientific researchers from different fields and to work on intensive field measurements to improve the understanding of the functioning of lake ecosystems. Another issue is to utilize the validated model to explore the effects of climate change on the water quality and planktonic biomass in the lake.

Supplementary Materials: The following are available online at https:/ /www.mdpi.com/article/10 $.3390 /$ su132212377/s1. Figure S1. Comparison of vertical water temperature profiles between model simulations and observations at the buoy station in 2017 and 2018; Table S1. Governing parameters, descriptions, values, and units adopted in the water quality-ecological model.

Author Contributions: Conceptualization, W.-C.L.; methodology, W.-C.L. and H.-M.L.; software, H.-M.L.; validation, W.-C.L. and H.-M.L.; formal analysis, H.-M.L. and R.S.-W.Y.; investigation, W.-C.L.; resources, W.-C.L.; data curation, H.-M.L. and R.S.-W.Y.; writing-original draft preparation, W.-C.L.; writing-review and editing, W.-C.L., H.-M.L. and R.S.-W.Y.; visualization, H.-M.L.; supervision, W.-C.L.; project administration, W.-C.L.; funding acquisition, W.-C.L. All authors have read and agreed to the published version of the manuscript.

Funding: This research was funded by the Ministry of Science and Technology, Taiwan (MOST 1062621-M-239-001 and 107-2621-M-239-001). The authors sincerely appreciate anonymous reviewers who provided useful comments to improve the article.

Institutional Review Board Statement: This study did not require ethical approval.

Informed Consent Statement: Not applicable.

Data Availability Statement: Not applicable.

Acknowledgments: The financial support is greatly appreciated. The authors also appreciate Y. Zhang at VIMS, College of William and Mary for sharing the source code of SCHISM.

Conflicts of Interest: The authors declare no conflict of interest.

\section{References}

1. Dodds, W.K.; Perkin, J.S.; Ferken, J.E. Human impact on freshwater ecosystem services: A global perspective. Environ. Sci. Technol. 2013, 47, 9061-9068. [CrossRef] [PubMed]

2. Kimura, N.; Liu, W.C.; Tsai, J.W.; Chiu, C.Y.; Kratz, T.K.; Tai, A. Contribution of extreme meteorological forcing to vertical mixing in a small, shallow subtropical lake. J. Limnol. 2017, 76, 116-128. [CrossRef]

3. Zhang, T.; Ban, X.; Wang, X.; Cai, X.; Li, E.; Wang, Z.; Yang, C.; Zhang, Q.; Lu, X. Analysis of nutrient transport and ecological response in Hinghu Lake, China by using a mathematical model. Sci. Total Environ. 2017, 575, 418-428. [CrossRef] [PubMed]

4. Janssen, A.B.G.; Janse, J.H.; Beusen, A.H.W.; Chang, M.; Harrison, J.A.; Huttunen, L.; Kong, X.; Rost, J.; Teurlincx, S.; Troost, T.A.; et al. How to model algal blooms in any lake on earth. Curr. Opin. Environ. Sustain. 2019, 36, 1-10. [CrossRef]

5. Soulignac, F.; Anneville, O.; Bouffard, D.; Chanudet, V.; Dambrine, E.; Guenand, Y.; Harmel, T.; Ibelings, B.W.; Trevisan, D.; Uittenbogaard, R.; et al. Contribution of 3D coupled hydrodynamic-ecological modeling to assess the representativeness of a sampling protocol to lake water quality assessment. Knowl. Manag. Aquat. Ecosyst. 2019, 420, 42. [CrossRef]

6. Chen, W.; Nielsen, A.; Andersen, T.K.; Hu, F.; Chou, Q.; Sondergaard, M.; Jeppesen, E.; Trolle, D. Modeling the ecological response of a temporarily summer-stratified lake to extreme heatwaves. Water 2020, 12, 94. [CrossRef]

7. Holguin-Gonzalez, J.E.; Everaert, G.; Boets, P.; Galvis, A.; Goethals, P.L.M. Development and application of an integrated ecological modelling framework to analyze the impact of wastewater discharges on the ecological water quality of rivers. Environ. Model. Softw. 2013, 48, 27-36. [CrossRef] 
8. Bucak, T.; Trolle, D.; Tavsanohlu, U.N.; Cakiroglu, A.I.; Ozen, A.; Jeppesen, E.; Beklioglu, M. Modeling the effect of climatic and land use change on phytoplankton and water quality of the largest Turkish freshwater lake: Lake Beysehi. Sci. Total Environ. 2018, 621, 802-816. [CrossRef] [PubMed]

9. Khwairakpam, E.; Khosa, R.; Gosain, A.; Nema, A. Monitoring and mode1ling water quality of Loktak Lake catchment. SN Appl. Sci. 2019, 1, 491. [CrossRef]

10. Hipsey, M.R.; Hamilton, D.P.; Hanson, P.C.; Carey, C.C.; Coletti, J.Z.; Read, J.S.; Ibelings, B.W.; Valesini, F.J.; Brookes, J.D. Predicting the resilience and recovery of aquatic systems: A framework for model evolution within environmental observatories. Water Resour. Res. 2015, 51, 7023-7043. [CrossRef]

11. Bocaniov, S.A.; Leon, L.F.; Rao, Y.R.; Schwab, D.J.; Scavia, D. Simulating the effect of nutrients on hypoxia in a large lake (Lake Erie, USA-Canada) with a three-dimensional lake model. J. Great Lakes Res. 2016, 42, 1228-1240. [CrossRef]

12. Chen, Y.; Song, L.; Liu, Y.; Yang, L.; Li, D. A review of the artificial neural network models for water quality prediction. Appl. Sci. 2020, 10, 5776. [CrossRef]

13. Crossman, J.; Bussi, G.; Whitehead, P.G.; Butterfield, D.; Lannergard, E.; Futter, M.N. A new, catchment-scale integragted water quality model of phosphorus, dissolved oxygen, biochemical oxygen demand and phytoplankton: INCA-phosphorus ecology (PEco). Water 2021, 13, 723. [CrossRef]

14. Amorim, L.F.; Martins, J.R.S.; Nogueira, F.F.; Silva, F.P.; Duarte, B.P.S.; Magalhaes, A.A.B.; Vincon-Leite, B. Hydrodynamic and ecological 3D modeling in tropical lakes. SN Appl. Sci. 2021, 3, 444. [CrossRef]

15. Sharip, Z.; Yanagawa, R.; Terasawa, T. Eco-hydrodynamic modelling of Chini Lake: Model description. Environ. Model. Assess. 2016, 21, 193-210. [CrossRef]

16. Gao, H.; Shi, Q.; Qian, X. A multi-species modelling approach to select appropriate submerged macrophyte species for ecological restoration in Gonghu Bay, Lake Taihu, China. Ecol. Model. 2017, 369, 179-188. [CrossRef]

17. Johnston, J.M.; Barber, M.C.; Wolfe, K.; Galvin, M.; Cyterski, M.; Parmar, R. An integral ecological modeling system for assessing impacts of multiple stressors on stream and riverine ecosystem services within river basins. Ecol. Model. 2017, 354, 104-114. [CrossRef] [PubMed]

18. Wang, Z.; Chai, F.; Dugdale, R.; Liu, Q.; Xue, H.; Wilkerson, F.; Chao, Y.; Zhang, Y.; Zhang, H. The interannual variabilities of chlorophyll and nutrients in San Francisco Bay: A modeling study. Ocean Dynam. 2020, 70, 1169-1186. [CrossRef]

19. Shalby, A.; Elshemy, M.; Zeidan, B.A. Assessment of climate change on water quality parameters of Lake Burullus, Egypt. Environ. Sci. Pollut. Res. 2020, 27, 32157-32178. [CrossRef]

20. Vigouroux, G.; Chen, Y.; Jonsson, A.; Cvetkovic, V.; Destouni, G. Simulaiton of nureient management and hydroclimic effects on coastal water quality and ecological status-The Baltic Himmerfjarden Bay case. Ocean Coast. Manag. 2020, 198, 105360. [CrossRef]

21. Khangaonkar, T.; Nugraha, A.; Premathilake, L.; Keister, J.; Borde, A. Projections of algae, eelgrass, and zooplankton ecological interactions in the inner Salish Sea-for future climate, and altered oceanic states. Ecol. Model. 2021, 441, 109420. [CrossRef]

22. Man, X.; Lei, C.; Carey, C.C.; Little, J.C. Relative performance of 1-D versus 3-D hydrodynamic, water-quality models for predicting water temperature and oxygen in a shallow, eutrophic, managed reservoir. Water 2021, 13, 88. [CrossRef]

23. Zhao, Y.W.; Xu, M.J.; Xu, F.; Wu, S.R.; Yin, X.A. Development of a zoning-based environmental ecological coupled model for lakes: A case study of Baiyangdian Lake in northern China. Hydrol. Earth Syst. Sci. 2014, 18, 2113-2126. [CrossRef]

24. Verhamme, E.M.; Redder, T.M.; Schlea, D.A.; Grush, J.; Bratton, J.F.; DePinto, J.V. Development of the Western Lake Eric Ecosystem Model (WLEEM): Applicaiton to connect phosphorus loads to cyanobacteria biomass. J. Great Lakes Res. 2016, 42, 1193-1205. [CrossRef]

25. Luo, L.; Wang, J.; Hunter, T.; Wang, D.; Vanderploeg, H.A. Modeling spring-summer phytoplankton bloom in Lake Michigan with and without riverine nutrient loading. Ocean Dynam. 2017, 67, 1481-1494. [CrossRef]

26. Makler-Pick, V.; Hipsey, M.R.; Zohary, T.; Carmel, Y.; Cal, G. Intraguild predication dynamics in a lake ecosystem based on a coupled hydrodynamic-ecological model: The example of Lake Kinneret (Israel). Biology 2017, 6, 22. [CrossRef] [PubMed]

27. Snortheim, C.A.; Hanson, P.C.; McMahon, K.D.; Read, J.S.; Carey, C.C.; Dugan, H.A. Meteorological drivers of hypolimnetic anoxia in eutrophic, north temperate lake. Ecol. Model. 2017, 343, 39-53. [CrossRef]

28. Couture, R.M.; Moe, S.J.; Lin, Y.; Kaste, O.; Haande, S.; Solheim, A.L. Simulating water quality and ecological status of Lake Vansjo, Norway, under land-use and climate change by linking process-oriented models with a Bayesian network. Sci. Total Environ. 2018, 621, 713-724. [CrossRef]

29. Luo, L.; Hamilton, D.P.; Lan, J.; McBride, C.; Trolle, D. Autocalibration of one-dimensional hydrodynamic-ecological model (DYRESM 4.0-CAEDYM 3.1) using a Monte Carlo approaches: Simulation of hypoxic events in a polymictic lake. Geosci. Model Dev. 2018, 11, 903-913. [CrossRef]

30. Fenocchi, A.; Rogora, M.; Morabito, G.; Marchetto, A.; Sibilla, S.; Dresti, C. Applicability of a one-dimensional coupled ecologicalhydrodynamic numerical model to future projections in a very deep large lake (Lake Maggiore, Northern Italy/Southern Switzerland). Ecol. Model. 2019, 392, 38-51. [CrossRef]

31. Bocaniov, S.A.; Lamb, K.G.; Liu, W.; Rao, Y.R.; Smith, R.E.H. High sensitivity of lake hypoxia to air temperature, winds, and nutrient loading: Insights from a 3-D lake model. Water Resour. Res. 2020, 56, e2019WR027040. [CrossRef]

32. Chiu, C.Y.; Jones, J.R.; Rusak, J.A.; Lin, H.C.; Nakayama, K.; Kratz, T.K.; Liu, W.C.; Tang, S.L.; Tsai, J.W. Terrestrial loads of dissolved organic matter drive inter-annual carbon flux in subtropical lakes during times of drought. Sci. Total Environ. 2020, 717, 137052. [CrossRef] [PubMed]

33. Liu, W.C.; Liu, H.M.; Chiu, C.Y. Investigating suspended-sediment transport in a shallow lake using a three-dimensional hydrodynamic and sediment model. J. Earth Syst. Sci. 2019, 128, 29. [CrossRef] 
34. Zhang, Y.J.; Ateljevich, E.; Yu, H.C.; Wu, C.H.; Tu, J.C.S. A new vertical coordinate system for a 3D unstructured-grid model. Ocean Model. 2015, 85, 16-31. [CrossRef]

35. Zhang, Y.J.; Ye, F.; Stanev, E.V.; Grashorn, S. Seamless cross-scale modeling with SCHISM. Ocean Model. 2016, 102, 64-81. [CrossRef]

36. Zhang, Y.; Baptista, A.M. SELFE: A semi-implicit Eulerian-Lagrangian finite-element model for cross-scale ocean circulation. Ocean Model. 2008, 21, 71-96. [CrossRef]

37. Umlauf, L.; Burchard, H. A generic length-scale equation for geophysical turbulence model. J. Mar. Res. 2003, 61, 235-265. [CrossRef]

38. Kantha, L.H.; Clayson, C.A. An improved mixed layer model for geophysical applications. J. Geophys. Res. 1994, 99, 25235-25266. [CrossRef]

39. Ye, F.; Zhang, Y.J.; Wang, H.V.; Friedrichs, M.A.M.; Irby, I.D.; Alteljevich, E.; Valle-Levinson, A.; Wang, Z.; Huang, H.; Shen, J.; et al. A 3D unstructured-grid model for Chesapeake Bay: Importance of bathymetry. Ocean Model. 2018, 127, 16-39. [CrossRef]

40. Chao, Y.; Farrara, J.D.; Zhang, H.; Zhang, Y.J.; Ateljevich, E.; Chai, F.; Davis, C.O.; Dugdale, R.; Wilkerson, F. Development, implementation, and validation of a modeling system for the San Francisco Bay and Estuary. Estuar. Coast. Shelf Sci. 2017, 194, 4056. [CrossRef]

41. Du, J.; Shen, J.; Zhang, Y.L.; Ye, F.; Liu, Z.; Wang, Z.; Wang, Y.P.; Yu, X.; Sisson, M.; Wang, H.V. Tidal response to sea-level-rsie in different types of estuaries: The importance of length, bathymetry, and geometry. Geophys. Res. Lett. 2017, 45, 227-235. [CrossRef]

42. Stanev, E.V.; Grashorn, S.; Zhang, Y.J. Cascading ocean basins: Numerical simulations of the circulation and interbasin exchange in the Azov-Black-Marmara-Mediterranean Seas system. Ocean Dynam. 2017, 67, 1003-1025. [CrossRef]

43. Liu, Q.; Anderson, E.J.; Zhang, Y.; Weinke, A.D.; Knapp, K.L.; Biddanda, B.A. Modeling reveals the role of coastal upwelling and hydrological inputs on biologically distinct water exchanges in a Great Lakes estuary. Estuar. Coast. Shelf Sci. 2018, 209, 41-55. [CrossRef]

44. Liu, Q.; Chai, F.; Dugdale, R.; Chao, Y.; Xue, H.; Rao, S.; Wilkerson, F.; Farrara, J.; Zhang, H.; Wang, Z.; et al. San Francisco Bay nutrients and plankton dynamics as simulated by a coupled hydrodynamic-ecosystem model. Cont. Shelf Res. 2018, 161, 29-48. [CrossRef]

45. Du, J.; Park, K.; Shen, J.; Zhang, Y.J.; Yu, X.; Ye, F.; Wang, Z.; Rabalais, N.N. A hysrosynamic model for Galveston Bay and the shelf in the northern Gulf of Mexico. Ocean Sci. 2019, 15, 951-966. [CrossRef]

46. Fortunato, A.B.; Meredith, E.P.; Rodrigue, M.; Freire, P.; Feldmann, H. Near-furture changes in storm surges along the Atlantic Iberian coast. Nat. Hazards 2019, 98, 1003-1020. [CrossRef]

47. Ye, F.; Zhang, Y.J.; Yu, H.; Sun, W.; Moghimi, S.; Myers, E.; Nunez, K.; Zhang, R.; Wang, H.V.; Roland, A.; et al. Simulating storm surge and compound flooding events with a creek-to-ocean model: Importance of baroclinic effects. Ocean Model. 2020, 145, 101526. [CrossRef]

48. Cai, X.; Zhang, Y.L.; Shen, J.; Wang, H.; Wang, Z.; Qin, Q.; Ye, F. A numerical study of hypoxia in Cheaspeake Bay using an unstructured grid model: Validaiton and sensitivty to bathymetry represetnation. J. Am. Water Resour. Assoc. 2021, in press.

49. Willmott, C.J. On the validation of models. Phys. Geogr. 1981, 2, 184-194. [CrossRef]

50. Li, M.; Zhong, L.; Boicourt, W.C. Simulations of Chesapeake Bay estuary: Sensitivity to turbulence mixing parameterizations and comparison with observations. J. Geophys. Res. Oceans 2005, 110, 1-22. [CrossRef]

51. Megrey, B.A.; Rose, K.A.; Klumb, R.A.; Hay, D.E.; Werner, F.E.; Eslinger, D.L.; Smith, S.L. A bioenergetics-based population dynamics model of Pacific herring (Clupea harengus pallasi) coupled to a lower tropic level nutrient-phytoplankton-zooplankton model: Description, calibration, and sensitivity analysis. Ecol. Model. 2007, 202, 144-164. [CrossRef]

52. Gal, G.; Hipsey, M.R.; Parparov, A.; Wagner, U.; Makler, V.; Zohary, T. Implementation of ecological modeling as effective management and investigation tool: Lake Kinneret as a case study. Ecol. Model. 2009, 220, 1697-1718. [CrossRef]

53. Huang, J.; Gao, J.; Hormann, G.; Fohrer, N. Modeling the effects of environmental variables on short-term spatial changes in phytoplankton biomass in a large shallow lake, Lake Taihu. Environ. Earth Sci. 2014, 72, 3609-3621. [CrossRef]

54. Li, Y.; Liu, Y.; Zhao, L.; Hastings, A.; Guo, H. Exploring change of internal nutrients cycling in a shallow ale: A dynamic nutrient driven phytoplankton model. Ecol. Model. 2015, 313, 137-148. [CrossRef]

55. Bowie, G.L.; Mills, W.B.; Porcella, D.B.; Campbell, C.L.; Pagenkopf, J.R.; Rupp, G.L.; Johnson, K.M.; Chan, P.W.H.; Cherini, S.A.; Chamberlin, C.E. Rates, Constants and Kinetics Formulations in Surface Water Quality Modeling, 2nd ed.; EPA/600/0-85/040; Environmental Research Laboratory, US EAP: Washington, DC, USA, 1985; 455p.

56. Park, K.; Kuo, A.Y.; Shen, J.; Hamrick, J.M. A Three-Dimensional Hydrodynamic-Eutrophication Model (HEM-3D): Description of Water Quality and Sediment Process Submodels; Special Report in Applied Marine Science and Ocean Engineering No.37; School of Marine Sciences, Virginia Institute of Marine Sciences, College of William and Mary: Williamsburg, VA, USA, 1995.

57. Hirst, A.G.; Bunker, A.J. Growth of marine planktonic copepods: Global rates and pattern in relation to chlorophyll a, temperature, and body weight. Limnol. Oceanogr. 2003, 48, 1988-2010. [CrossRef]

58. DiToro, D.; Fitzpatrick, J.; Thomann, R. Water Quality Analysis Simulation Program (WASP); US EAP: Washington, DC, USA, 2008.

59. Wang, C.F.; Hsu, M.H.; Liu, W.C.; Hwang, J.S.; Wu, J.T.; Kuo, A.Y. Simulation of water quality and plankton dynamics in the Danshuei River estuary, Taiwan. J. Environ. Sci. Health A 2007, 42, 933-953. [CrossRef]

60. Tetra Tech, Inc. The Environmental Fluid Dynamics Code Theory and Computation Volume 3: Water Quality Module; Tetra Tech, Inc.: Fairfax, VA, USA, 2007; 90p.

61. Kerimoglu, O.; Jacquet, S.; Vinvon-Leite, B.; Lemaire, B.J.; Rimet, F.; Soulignac, F.; Trevisan, D.; Anneville, O. Modelling the plankton groups of the deep, peri-alpine Lake Bourget. Ecol. Model. 2017, 359, 415-433. [CrossRef]

62. Hipsey, M.R.; Bruce, L.C.; Boon, C.; Busch, B.; Carey, C.C.; Hamilton, D.P.; Hanson, P.C.; Read, J.S.; de Sousa, E.; Weber, M.; et al A General Lake Model (GLM 3.0) for linking high-frequency sensor data from the Global Lake Ecological Observatory Network (GLEON). Geosci. Model Develop. 2019, 12, 473-523. [CrossRef] 
63. Gebre, S.; Biossy, T.; Alfredsen, K. Sensitivity to climate change of the thermal structure and ice cover regime of three hydropower reservoirs. J. Hydrol. 2014, 510, 208-277. [CrossRef]

64. Dou, M.; Ma, X.; Zhang, Y.; Zhang, Y.Y.; Shi, Y. Modeling the interaction of light and nutrients as factors driving lake eutrophication. Ecol. Model. 2019, 400, 41-52. [CrossRef]

65. Fenocchi, A.; Rogora, M.; Morabito, G.; Marchetto, A.; Sibilla, S.; Dresti, C. Model simulation of the ecological dynamics induced by climate cna nutreient load changes for deep subalpine Lake Maggiore (Italy/Switzerland). J. Limnol. 2020, 79, 221-237. [CrossRef]

66. Leon, L.F.; Smith, R.E.H.; Hipsey, M.R.; Bocaniov, S.A.; Higgins, S.N.; Hecky, R.E.; Antenucci, J.P.; Imberger, J.A.; Guildford, S.J. Application of a 3D hydrodynamic-biological model for seasonal and spatial dynamics of water quality and phytoplankton in Lake Erie. J. Great Lakes Res. 2011, 37, 41-53. [CrossRef]

67. Park, Y.; Cho, K.H.; Kang, J.H.; Lee, S.W.; Kim, J.H. Developing a flow control strategy to reduce nutrient load in a reclaimed multi-reservoir system using a 2D hydrodynamic and water quality model. Sci. Total. Environ. 2014, 466-467, 871-880. [CrossRef] [PubMed] 